\title{
Oncogene addiction: setting the stage for molecularly targeted cancer therapy
}

\author{
Sreenath V. Sharma and Jeffrey Settleman ${ }^{1}$ \\ Center for Molecular Therapeutics, Massachusetts General Hospital Cancer Center and Harvard Medical School, \\ Charlestown, Massachusetts 02129, USA
}

\begin{abstract}
In pugilistic parlance, the one-two punch is a devastating combination of blows, with the first punch setting the stage and the second delivering the knock-out. This analogy can be extended to molecularly targeted cancer therapies, with oncogene addiction serving to set the stage for tumor cell killing by a targeted therapeutic agent. While in vitro and in vivo examples abound documenting the existence of this phenomenon, the mechanistic underpinnings that govern oncogene addiction are just beginning to emerge. Our current inability to fully exploit this weakness of cancer cells stems from an incomplete understanding of oncogene addiction, which nonetheless represents one of the rare chinks in the formidable armor of cancer cells.
\end{abstract}

'Oncogene addiction': defining the term

Cancer is, an old adage goes, actually a hundred diseases masquerading as one. In our fight against this dreaded disease, casualties abound and successes are few and far between. Given the bewildering diversity of causality, it is gratifying to realize that painstaking investigation over the past 50 years has highlighted some common themes in the genesis and progression of cancer (Hanahan and Weinberg 2000). These commonalities offer a glimmer of hope that potential targets may exist within the cancer cell that can be exploited in combating these diseases. The first unifying theme is that cancer is caused by a handful of "rogue" corrupted cellular genes, designated oncogenes, that hijack the cell, causing it to survive indefinitely and proliferate aberrantly. The second unifying theme is that the genesis and progression of a tumor is governed by the activation of specific oncogenes and inactivation of tumor suppressor genes, and the stochastic accumulation of these genetic alterations progressively drives the evolution of cancer from a benign expansion of cells to an invasive and metastatic tumor. This is well illustrated by the example of colorectal cancer (Kinzler and Vogelstein 1996).

On the face of it, this would suggest that cancer is a

[Keywords: Oncogene addiction; cancer; targeted therapy; signal transduction]

${ }^{1}$ Corresponding author.

E-MAIL settleman@helix.mgh.harvard.edu; FAX (617) 726-7808.

Article is online at http://www.genesdev.org/cgi/doi/10.1101/gad.1609907. "moving target" that may be impossible to destroy. However, recently, a third common theme has begun to emerge that offers cause for guarded optimism. This phenomenon, referred to as "oncogene addiction," a term first coined in 2000 by Bernard Weinstein, reveals a possible "Achilles' heel" within the cancer cell that can be exploited therapeutically (Weinstein 2000, 2002; Weinstein and Joe 2006). In its simplest embodiment, oncogene addiction refers to the curious observation that a tumor cell, despite its plethora of genetic alterations, can seemingly exhibit dependence on a single oncogenic pathway or protein for its sustained proliferation and/or survival. At first glance, the fact that a tumor cell can exhibit dependency on a single protein that contributed to the malignant phenotype at some point in its history may seem to be trivial. However, the fact that inactivating the normal counterpart of such oncogenic proteins in normal tissues is often tolerated without obvious consequence highlights the unique state of addiction that appears to arise in cancer. A profound implication of this hypothesis is that switching off this crucial pathway upon which cancer cells have become dependent should have devastating effects on the cancer cell while sparing normal cells that are not similarly addicted. This, of course, is the discriminating activity required for any effective cancer therapeutic.

\section{Models of oncogene addiction}

Long before its articulation in 2000, hindsight reveals that several experimental findings reported in the literature could be explained by invoking oncogene addiction. These originate from a variety of settings, including human cancer cell lines, mouse tumor models, and clinical cancer studies (Table 1). In retrospect, the earliest evidence of oncogene addiction can be traced back to studies using human tumor-derived cell lines. That such a phenomenon can be observed in cell lines at all is remarkable in and of itself, since cell lines, which are often maintained in culture for prolonged periods, presumably accrue genetic alterations and undergo genetic drift over time, resulting from the genomic instability inherent in cancer. Moreover, cell lines are subject to the artificial pressures imposed by growth under nonphysiological conditions. Despite such pressures and the collateral 
Table 1. Examples of dominant oncogenes that confer oncogene addiction

\begin{tabular}{|c|c|c|c|c|}
\hline \multirow[b]{2}{*}{ Oncogene } & \multirow[b]{2}{*}{ Cancer } & \multicolumn{3}{|c|}{ Oncogene addiction and oncogenic shock } \\
\hline & & Cell lines & Mouse models & Clinical (approved) \\
\hline MYC & $\begin{array}{l}\text { Lymphoma, } \\
\text { leukemia }\end{array}$ & $\begin{array}{l}\text { RI (Yokoyama and Imamato } \\
\text { 1987; Loke et al. 1988) }\end{array}$ & $\begin{array}{l}\text { IE (Felsher and Bishop 1999; } \\
\text { Wu et al. 2007) }\end{array}$ & \\
\hline RAS & $\begin{array}{l}\text { Pancreatic, } \\
\text { thyroid, colon, } \\
\text { NSCLC }\end{array}$ & $\begin{array}{l}\text { RI (Mukhopadhyay et al. 1991; } \\
\text { Tokunaga et al. 2000) } \\
\text { SMI (Kohl et al. 1994; Liu } \\
\text { et al. 1998) }\end{array}$ & $\begin{array}{l}\text { H-RAS (Chin et al. 1999); } \\
\text { K-RAS (Fisher et al. 2001) }\end{array}$ & \\
\hline HER2 & $\begin{array}{l}\text { Breast, ovarian, } \\
\text { NSCLC }\end{array}$ & $\begin{array}{l}\text { Ab (Hudziak et al. 1989) } \\
\text { RI (Brysch et al. 1994; } \\
\text { Colomer et al. 1994) }\end{array}$ & $\begin{array}{l}\text { Ab (Shepard et al. 1991; } \\
\text { Ohnishi et al. 1995; Tokuda } \\
\text { et al. 1996) SMI (Xia et al. } \\
\text { 2002; Rabindran et al. 2004; } \\
\text { Wong et al. 2006) }\end{array}$ & $\begin{array}{l}\text { Trastuzumab/Herceptin } \\
\text { (Breast cancer); Lapatinib/ } \\
\text { Tykerb (Herceptin refractory } \\
\text { breast cancer) }\end{array}$ \\
\hline$B R A F$ & $\begin{array}{l}\text { Melanoma, } \\
\text { thyroid, } \\
\text { colorectal }\end{array}$ & $\begin{array}{l}\text { RI (Hingorani et al. 2003; } \\
\text { Sumimoto et al. 2004) } \\
\text { SMI (Karasarides et al. 2004) }\end{array}$ & $\begin{array}{l}\text { SMI (Karasarides et al. 2004; } \\
\text { Sharma et al. 2005) }\end{array}$ & $\begin{array}{l}\text { Sorafenib/Nexavar (Renal cell } \\
\text { carcinoma) }\end{array}$ \\
\hline EGFR & $\begin{array}{l}\text { NSCLC, } \\
\text { glioblastoma, } \\
\text { colon, pancreas }\end{array}$ & $\begin{array}{l}\text { RI (Yamazaki et al. 1998; } \\
\text { Halatsch et al. 2000; } \\
\text { Sordella et al. 2004) } \\
\text { Ab (Luwor et al. 2001) }\end{array}$ & $\begin{array}{l}\text { SMI (Ji et al. 2006a,b; Politi et } \\
\text { al. 2006) Ab (Luwor et al. } \\
\text { 2001) }\end{array}$ & $\begin{array}{l}\text { Gefitinib/Iressa (NSCLC); } \\
\text { Erlotinib/Tarceva (NSCLC, } \\
\text { pancreatic cancer); } \\
\text { Cetuximab/Erbitux (head } \\
\text { and neck, colorectal cancer); } \\
\text { Pantiumumab/ } \\
\text { Vectibix (colorectal cancer) }\end{array}$ \\
\hline MET & Gastric, NSCLC & $\begin{array}{l}\text { RI (Stabile et al. 2004; Ma et } \\
\text { al. 2005) SMI (Sattler et al. } \\
\text { 2003; Ma et al. 2005; } \\
\text { Smolen et al. 2006) }\end{array}$ & $\begin{array}{l}\text { RI (Stabile et al. 2004); } \\
\text { SMI (Puri et al. 2007; Zou et } \\
\text { al. 2007) Ab (Cao et al. 2001; } \\
\text { Burgess et al. 2006) }\end{array}$ & \\
\hline$A B L$ & CML & $\begin{array}{l}\text { SMI (Druker et al. 1996; } \\
\text { Carroll et al. 1997; Deininger } \\
\text { et al. 1997; Golas et al. } \\
\text { 2003) RI (Smetsers et al. } \\
\text { 1994) }\end{array}$ & $\begin{array}{l}\text { RI (Skorski et al. 1994) } \\
\text { SMI (Golas et al. 2003) }\end{array}$ & $\begin{array}{l}\text { Imatinib/Gleevec }\left(P h^{*} C M L\right. \\
\left.\quad P h^{*} A L L\right)\end{array}$ \\
\hline PDGFR & Glioma, GIST & SMI (Shawver 1997) & $\begin{array}{l}\text { SMI (Laird et al. 2000; Kilic } \\
\text { 2000; Blaskovich 2000) }\end{array}$ & $\begin{array}{l}\text { Imatinib/Gleevec (GIST) } \\
\text { Sunitinib/Sutent (GIST, } \\
\text { Renal cell carcinoma) }\end{array}$ \\
\hline KIT & GIST & $\begin{array}{l}\text { SMI (Tuveson et al. 2001; } \\
\text { Prenen et al. 2006) }\end{array}$ & $\begin{array}{l}\text { SMI (Decaudin et al. 2005; } \\
\text { Garton et al. 2006) }\end{array}$ & Imatinib/Gleevec (GIST) \\
\hline FGFR3 & Myeloma & $\begin{array}{l}\text { Ab (Trudel et al. 2006) } \\
\text { SMI (Trudel et al. 2004, } \\
\text { 2005; Chen et al. 2005; } \\
\text { Grand et al. 2004; Paterson } \\
\text { et al. 2004) }\end{array}$ & $\begin{array}{l}\text { SMI (Trudel et al. 2004, 2005; } \\
\text { Paterson et al. 2004) } \\
\text { Ab (Trudel et al. 2006) }\end{array}$ & \\
\hline$A L K$ & ALCL & $\begin{array}{l}\text { RI (Piva et al. 2006; Hsu et al. } \\
\text { 2007) SMI (Galkin et al. } \\
\text { 2007) }\end{array}$ & SMI (Galkin et al. 2007) & \\
\hline $\begin{array}{l}\text { AURORA } \\
\text { KINASE }\end{array}$ & Colon, breast & $\begin{array}{l}\text { SMI (Emanuel et al. 2005; } \\
\text { Soncini et al. 2006) RI (Hata } \\
\text { et al. 2005) }\end{array}$ & $\begin{array}{l}\text { SMI (Harrington et al. 2004; } \\
\text { Emanuel et al. 2005; Soncini } \\
\text { et al. 2006; Manfredi et al. } \\
\text { 2007; Wilkinson et al. 2007) }\end{array}$ & \\
\hline RET & Thyroid & $\begin{array}{l}\text { RI (Parthasarathy et al. 1999); } \\
\text { DN (Drosten et al. 2002) } \\
\text { SMI (Akeno-Stuart et al. } \\
\text { 2007; Mologni et al. 2006) }\end{array}$ & $\begin{array}{l}\text { DN (Drosten et al. 2003) } \\
\text { SMI (Petrangolini et al. 2006; } \\
\text { Akeno-Stuart et al. 2007) }\end{array}$ & \\
\hline$V E G F$ & $\begin{array}{l}\text { Tumor } \\
\text { angiogenesis }\end{array}$ & & $\begin{array}{l}\text { Ab (Kim et al. 1993; Kondo et } \\
\text { al. 1993); SMI (Sola et al. } \\
\text { 1995); RI (Saleh et al. 1996; } \\
\text { Cheng et al. 1996) }\end{array}$ & $\begin{array}{l}\text { Bevacizumab/Avastin } \\
\text { (Metastatic, colorectal } \\
\text { cancer); Sunitinib/ } \\
\text { Sutent (GIST, Renal cell } \\
\text { carcinoma); Sorafenib/ } \\
\text { Nexavar (Renal cell } \\
\text { carcinoma) }\end{array}$ \\
\hline
\end{tabular}

(RI) RNA interference; (IE) inducible expression; (SMI) small-molecule inhibitors; (Ab) antibody; (DN) dominant negative. 
mutational baggage, many human tumor cell lines appear to retain dependency on the very same activated oncogenes as the tumor from which they were derived, and faithfully undergo either proliferative arrest, senescence, differentiation, or apoptosis upon inactivation of the miscreant oncogenic signal. Furthermore, the genetic lesion that renders a tumor susceptible to a targeted inhibitor, if present in a cell line, often confers the same degree of sensitivity to that inhibitor. The demonstration of oncogene addiction in tumor cell lines strongly implicates a cancer cell-autonomous response to acute oncoprotein inactivation, at least in some cases, which is largely independent of external factors such as stromal interactions. This further suggests that oncogene addiction is a trait that must be beneficial-if not essential - to the survival of the tumor cell, and is therefore maintained in the face of genetic drift in culture. In fact, it is probably not unreasonable to postulate that most, if not all, dramatic responses of "tumor shrinkage" following molecularly targeted therapy result from the acute inactivation of an activated oncoprotein upon which the tumor cells became dependent.

MYC was among the first oncogenes to be identified, and its deregulated expression is widespread in human cancer (Vita and Henriksson 2006). Disruption of MYC by antisense RNA in human tumor-derived cell lines, leading to inhibition of proliferation and induction of differentiation (Yokoyama and Imamoto 1987; Loke et al. 1988), serves as one of the first experimental demonstrations of oncogene addiction, even though the term itself did not come into existence until more than a decade later. The fact that acute inactivation of $M Y C$ in conditional mouse models of MYC-induced lymphoma and leukemia leads to the rapid induction of apoptosis and/or cellular senescence (Felsher and Bishop 1999; Arvanitis and Felsher 2006; Wu et al. 2007), albeit in a context-dependent manner (Beer et al. 2004; Boxer et al. 2004), supports a role for deregulated MYC in oncogene addiction. This experimental finding was among the first to be directly attributed to oncogene addiction (Jain et al. 2002; Weinstein 2002).

Mutations in $R A S$ genes (H-RAS, Ki-RAS, and N-RAS) occur in $30 \%$ of human cancers, and transgenic mouse models support their causative role in neoplasia (Schubbert et al. 2007). The use of inducible $H$-RAS and Ki-RAS oncogenes in mouse tumor models of melanoma and lung adenocarcinoma, respectively, has provided evidence that addiction to the RAS oncoprotein results in tumor cell apoptosis following the acute inactivation of the RAS oncoprotein (Chin et al. 1999; Fisher et al. 2001). These observations are supported by similar studies using human tumor-derived cell lines (see Table 1), highlighting the significance of the RAS signaling pathway as a therapeutic opportunity.

While tumor dependency on the well-studied "classical" oncogenes, such as MYC and RAS, has now been demonstrated in a variety of experimental models, more recent studies have begun to reveal additional classes of genes that may also confer a state of dependency in cancers when dysregulated. For example, oncogenic micro-
RNAs ("oncomirs") have emerged recently as important players in cancer (Esquela-Kerscher and Slack 2006). The apparent role of oncomirs in oncogene addiction is highlighted by the demonstration that antisense inhibition of $m i R-17-5 p$ and $m i R-20 a$ leads to apoptosis of lung cancer cells overexpressing the microRNA miR-17-92 (Matsubara et al. 2007). Thus, "oncomir addiction" may be yet another manifestation of oncogene addiction. However, the potentially pleiotropic action of oncomirs may prove to substantially limit the therapeutic opportunity that such addiction might otherwise present.

\section{Activated kinases: the "Achilles' heel" of many cancers}

Protein kinases appear to represent particularly important targets for cancer therapy. The fact that they are frequently activated by mutation and/or gene amplification highlights their role in a variety of human cancers and, consequently, they feature prominently in the cancer drug development pipelines of many biotechnology and pharmaceutical companies. The clinical success of the multikinase inhibitor imatinib in treating chronic myelogenous leukemia (CML) and gastrointestinal stromal tumors (GIST) essentially led to a paradigm shift in cancer treatment strategies, and represented some of the first examples of oncogene addiction in the context of cancer therapy. The ABL and platelet-derived growth factor receptor (PDGFR) tyrosine kinases, which are targets of imatinib, are often activated by chromosomal translocations (BCR-ABL, TEL-ABL, TEL-PDGFR). Tumor cell lines harboring these activated $A B L$ and $P D G F R$ alleles become addicted to them for their survival and, consequently, undergo apoptosis following acute inactivation of the ABL or PDGFR oncoproteins using RNA interference (RNAi) (Skorski et al. 1994; Smetsers et al. 1994) or targeted inhibitors such as imatinib and SKI-606 (Druker et al. 1996, 2001; Carroll et al. 1997; Deininger et al. 1997; Golas et al. 2003). Imatinib, which also targets the KIT receptor tyrosine kinase, causes apoptosis of small cell lung cancer (SCLC) cell lines addicted to the autocrine loop created by the expression of KIT as well as its ligand, stem cell factor (SCF) in these cells in culture or grown as xenografts (Krystal et al. 2000; Decaudin et al. 2005). In addition, mutations in KIT, frequently encountered in GIST (Hirota et al. 1998) renders these cells addicted to the KIT oncoprotein, and its inactivation by imatinib, SU11248/Sunitinib or OSI-930 leads to apoptosis of the tumor cells (Tuveson et al. 2001; Garton et al. 2006; Prenen et al. 2006). Interestingly, 35\% of GISTs lacking KIT mutations harbor mutations in PDGFR $\alpha$ (Heinrich et al. 2003b), and these tumor cells, which appear to be dependent on activated $\operatorname{PDGFR} \alpha$, undergo apoptosis following imatinib treatment (Heinrich et al. 2003a). The autocrine loop involving PDGFR has also been implicated in the etiology of gliomas (Nister et al. 1991; Fleming et al. 1992), and addiction to this pathway is suggested by the tumor cell inhibition seen upon treatment with small molecule inhibitors such as SU101/ leflunomide, SU6668 and STI571/Imatinib, and GFB-111 (Shawver et al. 1997; Blaskovich et al. 2000; Kilic et al. 
2000; Laird et al. 2000). The clinical activity of imatinib in multiple disease settings, together with numerous cancer cell line studies demonstrating an apoptotic response to drug treatment, suggests that clinical responses are likely to reflect a cancer cell-autonomous dependency on specific activated kinases for their survival.

Oncogene addiction may also contribute to the clinical success of agents that target the ErbB family receptor, ErbB2/HER2. The erbB2/HER2 oncogene is amplified in $25 \%-30 \%$ of breast cancers (Berger et al. 1988; Guerin et al. 1988), suggesting that these tumors may be addicted to HER2. Consistent with such dependency, breast cancer cells in culture or grown as xenografts in nude mice are preferentially growth inhibited by HER2-specific antibodies (Hudziak et al. 1989; Shepard et al. 1991; Ohnishi et al. 1995; Tokuda et al. 1996), antisense oligonucleotides (Brysch et al. 1994; Colomer et al. 1994) and HER2-targeted small molecule inhibitors such as lapatinib, HKI-272, and BMS-599626 (Xia et al. 2002; Rabindran et al. 2004; Wong et al. 2006). These findings formed the basis for the treatment of patients with HER2-amplified metastatic breast cancer with the HER2 targeted antibodies, Trastuzumab/Herceptin and Pertuzumab (Hudis 2007).

The use of selective epidermal growth factor receptor (EGFR) kinase inhibitors in lung cancer treatment represents yet another example of oncogene addiction that has yielded clinical success in a subset of patients with advanced disease that are otherwise refractory to conventional chemotherapy treatment. Mutations in the kinase domain of EGFR are found in a subset $(10 \%-20 \%)$ of non-small cell lung cancers (NSCLC), and dramatic clinical responses to treatment with the small molecule EGFR kinase inhibitors gefitinib and erlotinib have been well correlated with such mutations (Lynch et al. 2004; Paez et al. 2004; Pao et al. 2004; Sharma et al. 2007). Glioblastomas frequently harbor EGFR gene amplification (Libermann et al. 1985; Wong et al. 1987) as well as EGFR deletion mutations in the ligand-binding domain (EGFRvIII) (Yamazaki et al. 1990; Nishikawa et al. 1994), and these tumors appear to be similarly addicted to EGFR activating mutations. A role for oncogene addiction in these clinical settings is supported by in vitro studies using tumor cell lines as well as in transgenic mouse models (see Table 1).

In addition to the clinical successes that have been observed with a few inhibitors of kinases to which tumor cells have become addicted, there is accumulating preclinical data suggesting that this phenomenon may be applicable to a large number of other kinases, underscoring the potential broad importance of oncogene addiction in molecularly targeted cancer therapy. For example, one of the seminal findings of the cancer genome sequencing projects was the identification of recurrent activating $B R A F$ kinase mutations (predominantly $V 600 E$ ) in $70 \%$ of melanomas, $40 \%$ of thyroid cancers, and $20 \%$ of colorectal cancers (Davies et al. 2002). The fact that inhibition of oncogenic BRAF (V600E) by RNAi (Hingorani et al. 2003; Sumimoto et al. 2004) or small molecule inhibitors of the BRAF downstream target MEK, such as CI-1040 and its derivative PD0325901 (Solit et al. 2006) results in growth arrest followed by apoptosis of cancer cells harboring oncogenic BRAF mutations, and suggests that such tumors are BRAF-addicted. Similarly, BRAF inhibitors such as Sorafenib/ BAY 43-9006 (Karasarides et al. 2004; Sharma et al. 2005) cause growth arrest and apoptosis of human tumor cell lines and xenografts harboring the oncogenic variant of BRAF.

Accumulating data derived largely from cancer genome resequencing and comparative genome hybridization studies have also highlighted the likely role of "kinase addiction" in a variety of human cancers. For example, MET gene amplifications, as well as mutations and aberrant expression of the HGF/MET signaling pathway have been observed in a significant fraction of gastric cancers, lung cancers, glioblastomas, colorectal cancers, esophageal cancers, and prostate cancers. The fibroblast growth factor receptor 3 (FGFR3) is activated in $15 \%$ of multiple myelomas by a chromosomal translocation $\mathrm{t}(4 ; 14)(\mathrm{p} 16.3 ; \mathrm{q} 32.3)$ (Chesi et al. 1997). A chromosomal translocation that results in the generation of a fusion transcript between nucloplasmin (NPM) and anaplastic lymphoma kinase $(A L K)$ similarly leads to kinase activation in $\sim 60 \%$ of Anaplastic Large Cell Lymphomas (ALCL) (Morris et al. 1994). Recent studies implicating the EML4-ALK fusion oncoprotein in the etiology of NSCLC indicate another potential setting for $A L K$ addiction in human cancer (Soda et al. 2007). Aurora kinases are frequently amplified in a diverse array of human cancers such as leukemias and colon and pancreatic tumors (Marumoto et al. 2005). Lastly, the RET oncogene is frequently mutated in medullary thyroid carcinomas and a subset of papillary thyroid cancers (Drosten and Putzer 2006; Kondo et al. 2006). Underscoring the importance of oncogene addiction is the fact that in all the abovementioned cases (BRAF, MET, FGFR3, ALK, Aurora kinase, and RET), acute inactivation of the mutated kinase by a variety of methods in different systems typically results in growth inhibition or tumor cell death (see Table 1). These examples also highlight the fact that mutationally activated oncogenes, especially kinases, appear to represent cancer culprits that frequently contribute to a state of oncogene dependency.

\section{Tumor suppressor restoration: the flip side of oncogene addiction}

Just as acute inactivation of addicting oncoproteins frequently leads to cancer cell death, recent evidence points to similar outcomes engendered by the reintroduction of wild-type versions of tumor suppressor genes that are frequently inactivated in cancer cells (Table 2). This phenomenon, referred to as "tumor suppressor hypersensitivity" (Weinstein 2002), may represent another dimension of oncogene addiction, since it is likely that in the establishment of the oncogene addicted state, a prerequisite may involve the removal of support systems such as tumor suppressors that buttress normal cell survival. 
Table 2. Examples of tumor suppressor genes that confer oncogene addiction

\begin{tabular}{|c|c|c|c|}
\hline \multirow{2}{*}{$\begin{array}{l}\text { Tumor } \\
\text { suppressor }\end{array}$} & \multirow[b]{2}{*}{ Cancer } & \multicolumn{2}{|c|}{ Oncogene addiction and oncogenic } \\
\hline & & Cell lines & Mouse models \\
\hline $\mathrm{P} 53$ & Cervical, multiple & $\begin{array}{l}\text { Adachi et al. 1996; Gomez-Manzano et al. } \\
\text { 1996; Vater et al. } 1996 \text { SMI: Hietanen et } \\
\text { al. } 2000\end{array}$ & $\begin{array}{l}\text { Martins et al. 2006; Ventura et al. 2007; Xue } \\
\text { et al. } 2007\end{array}$ \\
\hline LKB1 & Peutz-Jeghers syndrome & Qanungo et al. 2003 & \\
\hline DLC-1 & Hepatocellular carcinoma & Zhou et al. 2004 & \\
\hline FHIT & Lung, cervical, breast & Roz et al. 2002; Sevignani et al. 2003 & Sevignani et al. 2003; Pichiorri et al. 2006 \\
\hline ARLTS1 & $\begin{array}{l}\text { Breast, ovarian, lung, } \\
\text { familial cancer }\end{array}$ & Petrocca et al. 2006 & Petrocca et al. 2006 \\
\hline IRF-1 & Leukemia & $\begin{array}{l}\text { Kim et al. 2004; Bouker et al. 2005; } \\
\text { Iliopoulos et al. } 2007\end{array}$ & Kim et al. 2004; Watson et al. 2006 \\
\hline WWOX & Lung, breast, prostate & $\begin{array}{l}\text { Fabbri et al. 2005; Qin et al. 2006; } \\
\text { Iliopoulos et al. } 2007\end{array}$ & $\begin{array}{l}\text { Fabbri et al. 2005; Qin et al. 2006; Iliopoulos } \\
\text { et al. } 2007\end{array}$ \\
\hline TESTIN & Breast, uterine & Sarti et al. 2005 & Sarti et al. 2005 \\
\hline PTEN & Gliomas & Tian et al. 1999 & \\
\hline
\end{tabular}

Nowhere is this phenomenon more evident than in the case of the p53 tumor suppressor pathway, which is inactivated in most human cancers (Soussi 2007; Vousden and Lane 2007). Consistent with "addiction to lack of tumor suppressor genes," reintroduction of wild-type p53 into cancer cell lines harboring mutant p53 or p53deficient cancer cells (Adachi et al. 1996; Gomez-Manzano et al. 1996; Vater et al. 1996), or stabilization of wild-type p53 by small molecule inhibitors (Hietanen et al. 2000), or even "conversion" of mutant p53 to a form structurally resembling wild-type p53 (Bykov et al. 2002), can result in cancer cell ablation or senescence in a context-specific manner. These findings formed the basis for the proposal that systemic reintroduction of $\mathrm{p} 53$ in cancer patients could result in selective toxicity to tumor cells (McCormick 2001). While translation of this concept to cancer patients remains to be realized, recent studies in transgenic mice provide proof of concept and lend validity to p53 restoration as a cancer therapeutic strategy (Martins et al. 2006; Ventura et al. 2007; Xue et al. 2007). Similar studies suggest that this concept may be extended to other tumor suppressors, such as LKB1, which is frequently mutated in Peutz-Jeghers syndrome and lung cancer, DLC-1 (deleted in liver cancer), FHIT (Fragile Histidine Triad gene), ARLTS1 (ADP-Ribosylation factor-Like Tumor Suppressor 1), IRF1 (Interferon Regulatory Factor 1), WWOX (WW domain-containing Oxidoreductase), TESTIN and PTEN (Phosphatase and Tensin homolog), among others (Table 2).

\section{The molecular basis of oncogene addiction}

Various hypotheses have been proposed to account for the phenomenon of oncogene addiction. In the genetic streamlining hypothesis (Mills et al. 2001; Kamb 2003), natural selection, fueled by genomic instability of cancer cells, is believed to result in the deterioration, through disuse, of certain signaling pathways operational in normal cells, and the emergence and pre-eminence of the oncogenic signaling pathway. Similarly, it has been sug- gested that signaling network abnormalities may lead to extragenic suppression and synthetic lethal interactions with activated oncogenes (Reddy and Kaelin 2002; Kaelin 2005). Thus, two genes are synthetically lethal if inactivation of either gene, but not both, is compatible with cell survival. Thus, in the cancer cell, the activating oncogene is believed to be in a synthetic lethal relationship with another gene that is inactivated in the cancer cell. It follows that under these circumstances elimination of the oncogene would lead to the death of the cancer cell but would not similarly affect other normal cells in which such a synthetic lethal relationship does not exist. In his original proposal, Bernard Weinstein postulated that "because of their bizarre circuitry, cancer cells suffer from 'gene addiction' and 'gene hypersensitivity' disorders that might be exploited in both cancer prevention and chemotherapy" (Weinstein 2000). While each of these hypotheses provides a theoretical explanation for the response of the addicted cancer cell to acute inactivation of the addicting oncogene, leading to the collapse of the "molecular house of cards" in the cancer cell, experimental evidence to support them is largely lacking.

We recently proposed a model referred to as "oncogenic shock" to account for the observed apoptotic outcome resulting from the acute inactivation of oncoproteins in addicted cancer cells (Sharma et al. 2006a,b; Sharma and Settleman 2006). According to this model, proapoptotic as well as prosurvival signals are both outputs emanating from the same addicting oncoprotein, and the differential decay rates associated with these two broad classes of signals following oncoprotein inactivation, leads to a signal imbalance that contributes to cell death (Fig. 1). Indeed, as detailed in the following section, evidence supporting such a duality of signaling output from many activated oncoproteins, including RAS, MYC, SRC, and EGFR, has been well established. Moreover, numerous studies indicate that tumors often exhibit enhanced apoptotic activity, and it has been suggested that tumor cells may be teetering on the threshold of an apoptotic outcome. 


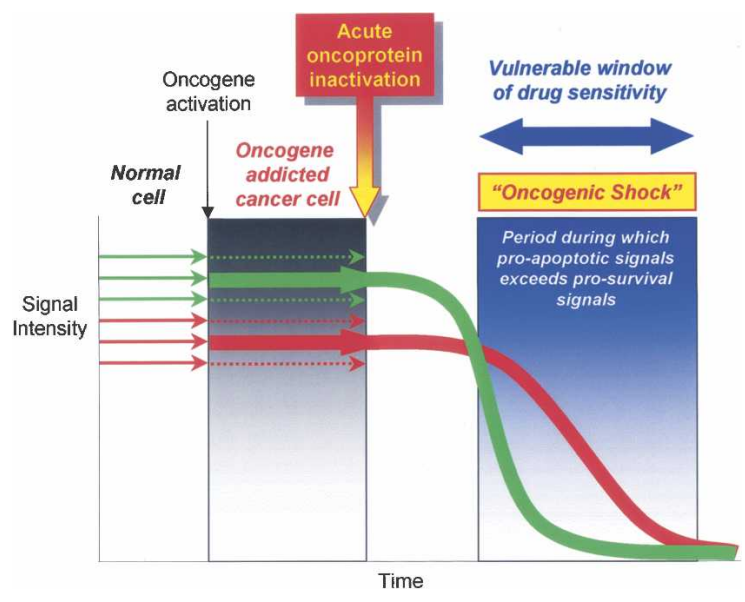

Figure 1. Model illustrating the relationship between oncogene addiction and oncogenic shock. In normal cells, numerous prosurvival signals (thin green arrows) predominate and keep the various proapoptotic stimuli (thin red arrows) in check, thus leading to normal cell homeostasis. In cancer cells, the activation of an oncogene results in an oncogene-addicted cancer cell (indicated by the black shaded box). In oncogene-addicted cancer cells, the pre-eminence of an oncoprotein results in the atrophy of other survival (dashed green arrows) and death (dashed red arrows) signals and the dominance of oncoprotein-dependent survival (thick green arrow) and death (thick red arrow) outputs. Even in this oncogene-addicted state, the survival outputs from the actively signaling oncoprotein predominate, thereby keeping the oncoprotein-induced death signal in check. Upon acute inactivation of the oncoprotein, "oncogenic shock" results in differential signal attenuation, associated with the rapid attenuation of oncoprotein-generated prosurvival signals, whereas the oncoprotein-induced proapoptotic signals linger sufficiently long such that the cell becomes committed to an apoptotic death. During this vulnerable window of time (indicated by the blue shaded box), the longer-lived proapoptotic signals gain the upper hand and cause the cells to irrevocably undergo apoptosis.

\section{Janus faces of oncogenes: Dr. Jekyll and Mr. Hyde}

Implicit in the oncogenic shock, genetic streamlining/ signaling network suppression, and synthetic lethality models is the paradoxical requirement that activated oncoproteins simultaneously generate both prosurvival and proapoptotic signals. While the prosurvival function of oncoproteins has long been recognized, their proapoptotic roles are only just beginning to be appreciated. The earliest evidence of such antagonistic duality in oncoprotein function came from studies of the MYC oncogene (Evan et al. 1994; Harrington et al. 1994b; Hueber and Evan 1998). The proapoptotic function of overexpressed MYC was manifest under conditions of reduced serum concentration (Evan et al. 1992), a common experimental treatment that, in retrospect, probably limited all other survival inputs and served to focus oncogene addiction/dependency on one critical survival pathway, thereby uncovering the proapoptotic function of oncoproteins operating along that pathway. This inference is supported by subsequent studies demonstrating that MYC-induced apoptosis is inhibited by specific cy- tokines (Harrington et al. 1994a) via the activation the PI-3 kinase/Akt pathway (Kauffmann-Zeh et al. 1997). MYC-induced cell death is mediated by apoptosis, as evidenced by its inhibition by BCL-2 (Bissonnette et al. 1992). Moreover, MYC-induced apoptosis plays a physiological role in antigen-induced negative selection of developing T cells (Shi et al. 1992) suggesting that it is not a cell culture oddity. The proapoptotic function of cMYC, and its negative regulation by BCL-2, have also been demonstrated in vivo using mouse models (Alarcon et al. 1996). Such antagonistic functional duality is an essential feature of oncoproteins that engender addiction.

The transcription factor E2F1 is an established prosurvival molecule that also exhibits proapoptotic activity that is dependent on the presence of wild-type p53/p73 and the absence of the $\mathrm{pRb}$ tumor suppressor (Qin et al. 1994; Wu and Levine 1994; Irwin et al. 2000). E2F1-mediated apoptosis results from the premature entry of cells into the S phase of the cell cycle followed by apoptotic cell death (Shan and Lee 1994; Kowalik et al. 1995), which requires its binding partner DP-1 (Hiebert et al. 1995; Shan et al. 1996), and is antagonized by the p53 regulator, MDM2 (Kowalik et al. 1998; Loughran and La Thangue 2000). Overexpressed as well as endogenous E2F1 participates in apoptosis, as demonstrated by suppression of apoptosis, and S-phase entry defects in E2F1deficient mice (Tsai et al. 1998). Thus, E2F1 exhibits dual "opposing" functions that are likely to be contextdependent in cancer cells.

Previous studies have shown similarly that the v-JUN oncoprotein is proapoptotic in the absence of growth factors and, like MYC, requires BCL-2 for this activity (Frisch et al. 1996; Clark and Gillespie 1997; MacLaren et al. 2000). Similar context-dependent dual opposing functions are exhibited by the JUN kinase, (JNK), and stress activated protein kinase, p38 (Xia et al. 1995). A proapoptotic function has also been reported for c-FOS (Preston et al. 1996, 2000) and this activity plays an important role in normal mouse development (Smeyne et al. 1993). In addition to the oncogenic transcription factors discussed thus far, proapoptotic roles have also been uncovered for cytoplasmic oncoproteins such as RAF and RAS. Sustained high-level expression of oncogenic RAF in primary human cells leads to cell cycle arrest and premature senescence through the induction of the cyclin-dependent kinase inhibitors p16(Ink4a) and/or p21(Cip1) (Woods et al. 1997; Zhu et al. 1998; Fanton et al. 2001). The pre-eminence of $R A S$ oncogenes in human cancer might at first glance appear to be somewhat at odds with a proapoptotic role for this oncoprotein. Nonetheless, the proapoptotic functions of activated RAS and MYC are the best characterized among the numerous identified oncoproteins (Arber 1999). The first inkling for a proapoptotic role for oncogenic RAS emerged from experiments described more than 20 years ago, and subsequent studies demonstrated that this activity required PKC, BCL-2, p53, p16INK4a, p19ARF, NF-kB, and occurred in a caspase-independent manner /Chen and Faller 1995; Rak et al. 1995b; Wang et al. 1995; Miranda et al. 1996; Mayo et al. 1997; Serrano et al. 1997; Chen et 
al. 1998a,b; Gallagher et al. 1998; Chi et al. 1999; Groth et al. 2000; Ferbeyre et al. 2002).

Oncogenic tyrosine kinases such as SRC, ABL, and EGFR also demonstrate a dual pro- and anti-death function, although this has not been as well characterized in the two latter cases. Unlike the other oncoproteins described to this point, the proapoptotic function of oncoprotein tyrosine kinases is manifested primarily upon acute inactivation. Like MYC, the proapoptotic functions of v-SRC are revealed under low serum conditions and can be abrogated by the provision of serum growth factors or BCL-2 (Johnson et al. 2000; Webb et al. 2000; Sharma et al. 2006b). The primary survival pathways activated by $\mathrm{v}$-SRC are the MEK/ERK and the PI-3 kinase/ AKT pathways, and apoptosis following acute inactivation of the oncoprotein leads to attenuation of these pathways and the activation of p38 MAP (mitogen-activated protein) kinase proapoptotic pathways immediately preceding cell death (Johnson et al. 2000; Sharma et al. 2006b). A similar response is seen following acute inactivation of the BCR-ABL and mutationally activated EGFR kinases (Sharma et al. 2006b). This antagonistic duality even extends to viral oncoproteins such as adenovirus E1A (White and Stillman 1987) and papillomavirus E7 (Liu et al. 2000). Thus, it is quite possible that many if not all oncoproteins are similarly endowed with the dual "life and death" capability. The challenge for investigators lies in our ability to establish the particular context that will enable these opposing roles to be uncovered. The fact that cancer cells exhibit remarkably high levels of spontaneous cell death (in addition to their enhanced proliferative capacity) is a testament to this antagonistic duality of signaling and underscores the potential universality of this phenomenon in cancer. In this regard, it is very likely that in the context of activated oncogenes, cell proliferation, and apoptosis are tightly coupled, thereby providing a potential "Achilles' heel" of the cancer cell that can be exploited therapeutically (Evan and Littlewood 1998).

\section{Oncogene addiction and differential signal decay}

An important and therapeutically relevant feature of oncogene addiction relates to the tumor cell-specific induction of apoptosis, which begs the question: Why does inactivation of the corresponding proto-oncogenes not lead to a similar outcome in normal cells? This question is particularly germane in light of the fact that most clinically used targeted kinase inhibitors, for example, are not completely specific for oncogenic proteins, and, in all likelihood, also inhibit their normal counterparts. Although activating EGFR mutants are biochemically more sensitive to EGFR inhibition (Mulloy et al. 2007), wild-type and mutant EGFR proteins are both efficiently inhibited at clinically relevant drug concentrations, suggesting that this differential biochemical sensitivity is unlikely to explain the clinical responses in EGFR mutant tumors. While a definitive answer to this question awaits further analysis, one possibility is that the attenuation of signals emanating from an actively signaling ki- nase, for example, is a well-orchestrated process in which the apoptotic output is balanced with a sufficient anti-apoptotic output. The excessive, and sometimes qualitatively altered signaling downstream from an activated oncoprotein, on the other hand, may result in disruption of a carefully orchestrated signal attenuation process that normally occurs in nonmalignant cells.

Alternatively, it is possible that the excessive apoptotic signals derived from activated oncoproteins in cancer cells shifts the "balance of power" such that the slightest disruption of survival signaling following oncoprotein inactivation rapidly leads to an apoptotic outcome. Thus, in a viable tumor cell, it is likely that prosurvival signals emanating from an active oncoprotein predominate and keep the proapoptotic signals "in check." While excessive survival signals, as well as death signals, are probably being transduced within many cancer cells, the balance between these signals clearly favors the survival of the tumor cell. However, upon acute oncoprotein inactivation following exposure to an inhibitor of the addicting oncoprotein, prosurvival signals are observed to decay rapidly, while proapoptotic outputs, which appear to be longer lived, persist for many hours (Sharma et al. 2006b). Thus, for a brief period of time following acute oncoprotein inactivation, a signaling imbalance results in the predominance of proapoptotic signals in the cell. This "differential signal decay" leading to a temporary predominance of proapoptotic outputs sets the apoptotic cascade in motion, thereby committing the cancer cell irrevocably to apoptosis (Fig. 1). Such differential signal decay constitutes the essence of the oncogenic shock model and is equally consistent with genetic streamlining/signaling network suppression and synthetic lethality, although we hasten to add that rigorous proof of this mechanism remains to be established, and in this regard, these models are largely theoretical. Nevertheless, it is important to consider oncogene addiction and oncogenic shock as interdependent phenomena, with oncogene addiction describing the state of the cancer cell before the acute inactivation of the oncoprotein and oncogenic shock describing the potential consequence of acute inactivation of the addicting oncoprotein.

\section{Factors influencing oncogene addiction}

As described above, acute oncoprotein inactivation in cancer cells often results in apoptosis. Therefore, factors that influence apoptosis are likely to influence the response to oncoprotein inactivation in oncogene-addicted tumors. It has long been recognized that dysregulated cell proliferation and suppression of apoptosis are hallmarks of cancer (Hanahan and Weinberg 2000; Evan and Vousden 2001; Green and Evan 2002; Lowe et al. 2004). Indeed, cancer cells deploy a diverse array of mechanisms to avoid apoptosis, such as inhibition of cell death mediating proteins (Soengas et al. 2001; Lowe et al. 2004) and/or overexpression of cell death inhibitory proteins of the BCL-2 or IAP (inhibitors of apoptosis) family (Cory and Adams 2002; Salvesen and Duckett 2002; Danial and 
Korsmeyer 2004). One such member of the IAP family, survivin, that is frequently expressed in human cancers provides a link between cell cycle progression and apoptosis by inhibiting the proapoptotic protein Caspase-3 (Li et al. 1998; Li et al. 1999). Similarly, the transcription regulator Id3 closely couples G1-stage cell cycle progression and apoptosis (Norton and Atherton 1998; Sikder et al. 2003).

The genetic constitution of the tumor cell, aside from a single addicting oncogene, will almost certainly influence the response to oncoprotein inactivation. For example, mutations in the ARF/p53 pathway potently attenuate the proapoptotic and/or prosenescence properties of oncogenic BCR-ABL, and tumors harboring such mutations appear to be particularly resistant to imatinib (Williams et al. 2006, 2007). This might help to explain the failure of targeted therapies in certain tumors despite the presence of activating mutations in oncogenes that might otherwise confer a state of addiction.

It is also important to consider that cancer cells are under the influence of signals both from within the cell, as well as from the external microenvironment in which they exist. The relationship of a tumor with its microenvironment is a highly complex and symbiotic one in which the tumor cells influence the microenvironment, which in turn influences the tumor by providing a niche for optimal tumor growth (Shchors and Evan 2007). Components of the microenvironment that exist in such a "give-and-take" relationship with the tumor include the extracellular matrix on which the tumors grow and the vasculature that nourishes and sustains them. Attracting the vasculature (angiogenesis) is particularly important in the transition of a benign tumor to malignancy, a phenomenon termed the "angiogenic switch" (Folkman and Hanahan 1991). Addicting oncoproteins such as RAS and MYC have a propensity to turn on this angiogenic switch by inducing the expression of matrix metalloproteinases (MMP), especially MMP-9, (Bernhard et al. 1994) and inhibition of MMP-9 blocks the metastatic capability of such tumors (Hua and Muschel 1996). Tumors harboring activated RAS are capable of activating the angiogenic switch by up-regulating vascular endothelial growth factor (VEGF) and MMP (Arbiser et al. 1997). Similarly, EGF as well as activated EGFR, both, induce the expression of VEGF via PI3 kinase in glioblastomas (Goldman et al. 1993; Petit et al. 1997; Maity et al. 2000; Clarke et al. 2001; Casanova et al. 2002). Consistent with this, dual inhibition of EGFR and VEGFR induces potent anti-tumor effects in mouse tumor models (Sini et al. 2005; Younes et al. 2006) and provides the rationale for ongoing clinical testing of several multitargeted kinase inhibitors such as ZD-6474, AEE 788, and XL647 (Sharma et al. 2007). Oncogenic H-RAS or Ki-RAS as well as oncogenic SRC and RAF all up-regulate a variety of cytokines and growth factors that either directly or indirectly induce angiogenesis (Rak et al. 1995a). Similarly, the MET receptor ligand, hepatocyte growth factor, also induces VEGFR expression, which may serve to increase tumor angiogenesis in MET-addicted tumors
(Moriyama et al. 1998; Van Belle et al. 1998; Dong et al. 2001).

Another mechanism by which tumors might throw the angiogenic switch relates to the architecture of the tumor itself. The hypoxic interior of the tumor may be sufficient to trigger angiogenesis via the induction of hypoxia-inducible factors (HIFs), a family of proteins whose diverse targets include a multitude of proangiogenic mediators such as inducible nitric oxide synthase (iNOS), VEGF, EGF, PDGF, and basic FGF (Liao and Johnson 2007). This interdependency of tumors with the vasculature forms the basis for anti-angiogenic therapy using agents such as bevacizumab (Avastin), a humanized monoclonal anti-vascular antibody targeting VEGF or small molecule inhibitors that target VEGF such as BAY43-9006/Sorafenib, SU11248/Sunitinib (Kerbel 2006). However, it should be noted that the clinical activity of VEGF-targeted drugs might simply reflect tumor "starvation," as opposed to oncogene addiction. Furthermore, the contribution of the tumor environment to the state of oncogene dependency implicates tumor cell-nonautonomous mechanisms in at least some cases of oncogene addiction.

\section{Clinical implications of oncogene addiction}

The striking correlation between the presence of activating mutations and/or gene amplifications of the target kinases of several clinically effective inhibitors and the response to treatment with those inhibitors highlights the potential importance of oncogene addiction in molecularly targeted cancer therapy. Indeed, the dual survival-apoptosis signaling output from such kinases, as described above, appears to have provided an exploitable therapeutic opportunity in which the oncoprotein can be essentially turned against the tumor cell by acutely disrupting the balance between these signals. Although this phenomenon has been limited thus far, in clinical settings, to a few of the known oncogenic kinases, including EGFR, HER2, BCR-ABL, PDGFR, and c-KIT, it is likely that efforts of the cancer genome sequencing projects currently underway will yield many additional candidate oncogenic kinases to which cancer cells potentially exhibit addiction, and may therefore constitute important targets for drug development. Along these lines, it is notable that preclinical cell-based studies suggest that oncogene addiction may also provide a therapeutic opportunity in the setting of gastric cancers and NSCLCs with an amplified MET kinase gene, and melanomas, thyroid, and colorectal cancers that harbor the recurrent BRAF mutation $V 600 E$, and clinical studies are underway to examine the efficacy of agents that target these kinases.

The oncogenic shock model may also have implications regarding the optimal strategy for treating patients with targeted inhibitors. Thus, it is possible that "pulse" treatment involving on-off cycles of drug administration, as opposed to the standard continuous treatment, could prove beneficial by providing more opportunities for the engagement of differential signal attenuation, 
leading to an increased probability of oncogenic shock and hence an apoptotic outcome. However, it may prove challenging to extrapolate the kinetic findings in cell culture studies to the timing of drug administration in vivo. The oncogenic shock model may also have implications for the use of drug combinations in cancer therapy. For example, many of the commonly used cancer chemotherapy drugs inhibit cell cycle progression and, consequently, might prevent the ability of cells to undergo cell cycle-dependent apoptosis when cotreated with such agents together with inhibitors of addicting oncoproteins.

A potential role for synthetic lethality in oncogene addiction may also lead to new therapeutic strategies. Thus, the identification of addiction settings involving codependence on two different oncogene products may lead to a rational combination treatment strategy involving simultaneous disruption of both genes. In theory, the phenomenon of tumor suppressor hypersensitivity (described above) could also lead to a therapeutic opportunity in which a tumor suppressor is reintroduced into cancer cells. However, technologies enabling efficient delivery of exogenous genes to tumor cells in vivo remain a substantial challenge.

\section{Acquired drug resistance and oncogene addiction}

The phenomenon of oncogene addiction has revealed potentially important therapeutic opportunities that can lead to the selective elimination of tumor cells that exhibit strict dependence on a protein that can be targeted pharmacologically. As described above, this is well exemplified by the experience with several of the clinically approved tyrosine kinase inhibitors, including imatinib, erlotinib, and trastuzimab, which target oncogenic kinases on which tumor cells have become dependent for survival. However, an important limitation of these agents is that clinical responses, in most cases, are relatively short-lived. This is most clearly illustrated in the case of erlotinib-responsive NSCLCs, a setting in which clinical responses, even when dramatic, typically average only 6-9 mo in duration, and are almost invariably followed by disease progression (Sharma et al. 2007). Such findings appear to reflect the acquisition of drug resistance by tumor cells, and some of the molecular mechanisms underlying such resistance are beginning to be elucidated. For example, secondary kinase domain mutations that affect the so-called "gatekeeper" residue of the BCR-ABL and EGFR kinases have been identified in tumors from patients with acquired resistance to inhibitors of these kinases. These mutations confer reduced drug binding while preserving oncogenic kinase activity, thereby providing a straightforward biochemical mechanism of acquired drug resistance (Daub et al. 2004; Pao et al. 2005).

In other cases of acquired drug resistance, tumor cells may engage an alternative or redundant survival pathway (Fig. 2). For example, a recent report revealed that a subset of NSCLC patients with acquired resistance to EGFR TKIs harbor tumors that exhibit amplification of the gene encoding the MET tyrosine kinase (Engelman et al. 2007). MET gene amplification in these cases was not detectable in the pretreatment biopsies, but was acquired during drug treatment. In these cases, it appears that MET, which can promote the activation of downstream survival pathways that overlap with those en-
Figure 2. Heterogeneity of tumor cell dependency as the basis for resistance to therapeutics targeting oncogene addiction. In this model, a tumor is considered to be a heterogeneous cell population comprised largely of cancer cells addicted to oncogene X (blue), but containing a small subpopulation of nonaddicted cancer cells, designated "persisters" (orange) that are characterized by very slow growth, a lack of dependency on the same survival signals as the bulk tumor population, and the ability to tolerate an initial onslaught of drug. Upon treatment with a therapeutic targeted to the addicting oncoprotein, tumor shrinkage results from ablation of the addicted cells, but persisters, by virtue of the fact that they are not oncogene addicted, are maintained. These persisters have the capacity to regenerate the tumor in three distinct ways: (1) The tumor will remain composed largely of cancer cells that remain addicted to the same oncogene $\mathrm{X}$ (blue: center scenario), in which case resistance appears to be reversible, possibly involving an epigenetic mechanism; (2) the tumor is largely composed of cells that have switched their addiction to an alternative oncogene $\mathrm{Y}$ (green: scenario shown on the right); or (3) the tumor will be comprised largely of cells that exhibit coaddiction to an oncogene $\mathrm{Y}$ in addition to the original addicting oncogene $\mathrm{X}$ (purple: scenario shown on the left).

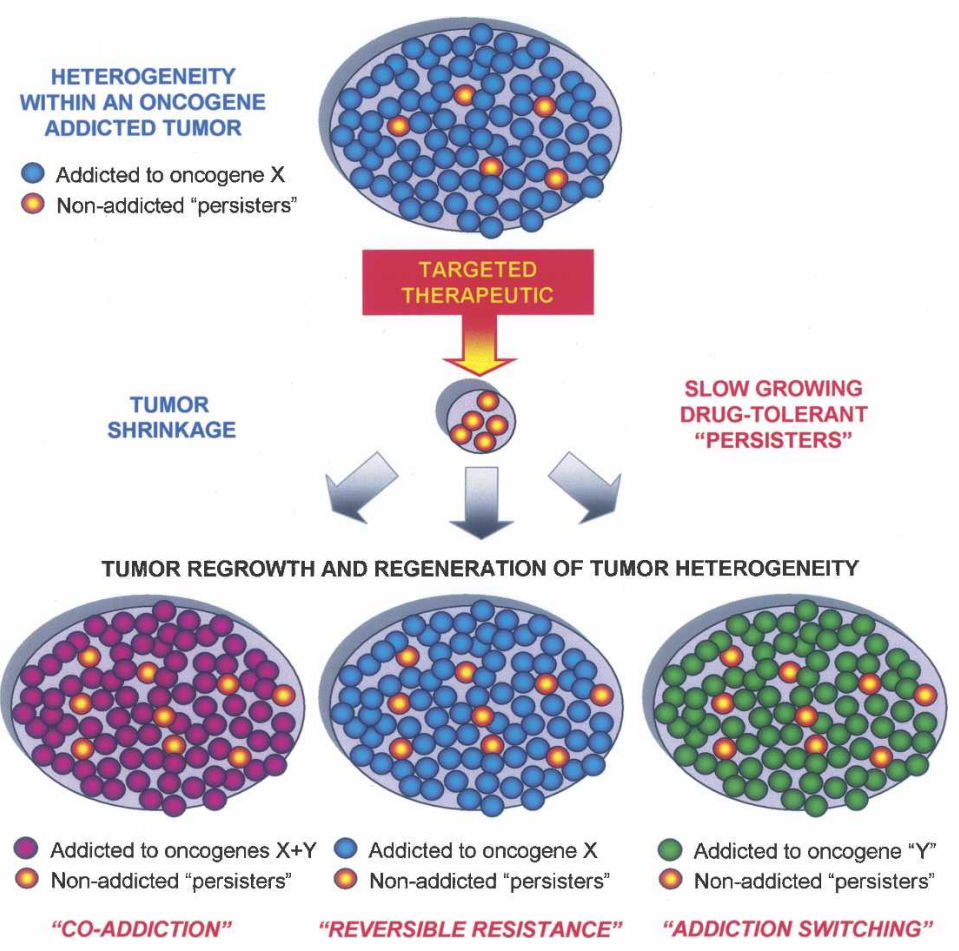


gaged by EGFR, may provide redundant survival signals, thereby relieving the cell of a specific requirement for the initially addicting oncoprotein, EGFR. Such tumor cells, which can be considered to be "coaddicted" to two convergent signaling pathways, might be effectively treated with a combination of EGFR and MET kinase inhibitors to overcome such redundant survival signals.

As an alternative mechanism of acquiring drug resistance in an oncogene addicted tumor cell, it is conceivable that drug-treated tumor cells could become entirely dependent on a second survival pathway (Fig. 2). Although such a mechanism has yet to be demonstrated in patients with acquired drug resistance, it is possible that such "addiction switching" underlies resistance in some cases, and that such patients would benefit from treatment with an inhibitor of the pathway or kinase to which the tumor cells have switched addiction during treatment with the initial drug. Since many of the receptor kinases that have been implicated in cancer can transduce signals to an overlapping set of downstream mediators of survival and proliferation, it is easy to envision the engagement of redundant or alternative upstream components of these signaling pathways as an addiction switching mechanism of drug resistance.

\section{Tumor cell heterogeneity and oncogene addiction}

The examples of acquired drug resistance in cells addicted to oncogenic kinase activity described above involve stable mutational mechanisms. Presumably, such mutations are present at very low frequency within the tumor cell population-arising through random or treatment-induced mutagenesis-and are subsequently selected during drug therapy. However, acquired resistance does not necessarily require mutational mechanisms. For example, it has been reported that a subset of NSCLC patients that initially respond to treatment with EGFR TKIs and subsequently relapse can be successfully retreated with EGFR TKIs following a "drug holiday" (Kurata et al. 2004; Yano et al. 2005; Yokouchi et al. 2007; Yoshimoto et al. 2007). Such findings implicate a reversible, and presumably nongenetic mechanism by which acquired drug resistance can develop.

In this context, the distinction between drug tolerance and drug resistance in this setting merits consideration. Thus, it is possible that the ability to tolerate an initial exposure to drug involves mechanisms distinct from those that allow the cell to maintain normal proliferative and survival functions in the continued presence of drug. A reversible drug resistance mechanism might reflect the presence of a small subset of cells within the tumor population that exists in a functionally distinct state characterized by an ability to tolerate external stresses such as drug exposure. This drug-tolerant state could allow these cells to withstand an initial onslaught of stress to promote their survival for a sufficient time period to enable more stable, or even permanent resistance mechanisms to be established (Fig. 2).

Such a drug-tolerant state may be analogous to a state described for various bacterial strains following exposure to antibiotics (Balaban et al. 2004). Several studies have demonstrated the existence of antibiotic-tolerant bacterial subpopulations, known as "persisters" or "sentinels," that are able to withstand potentially toxic stresses through the engagement of epigenetic survival mechanisms (Dhar and McKinney 2007). Bacterial persisters are generally slower growing cells, and their survival within a rapidly growing population, which consists predominantly of nonpersisters, is achieved because persisters are able to revert to a nonpersister state. Through this switching mechanism, the "burden" imposed on persisters to "protect" the population as a whole from potential eradication by external stresses is shared among the population (Lewis 2007).

An analogous stochastic switching mechanism may similarly be operative in human cancers. Thus, it is possible that a subpopulation of tumor cells with persisterlike properties is present within tumors, with survival of those cells coupled to signal transduction pathways distinct from those that determine survival of the majority of tumor cells within the population (Fig. 2). Such heterogeneity, involving a small subset of cells that can survive in the face of potentially toxic insults, may, as with antibiotic-tolerant bacteria, also be maintained via an epigenetic mechanism, and could similarly contribute to drug tolerance, followed by stable drug resistance, to ensure the long-term survival of the tumor. In this regard, it is interesting to consider the tumor cell population as a single "organism" whose survival potential is enhanced by the fact that the cells have not all coupled their survival to the same pathways. Thus, there may be heterogeneity with regard to the addicted state of the population. The nature of putative epigenetic mechanisms that might contribute to such heterogeneity among cells within a tumor population is unknown. Theoretically, it could potentially involve the up-regulation of an upstream activator of survival signaling distinct from that to which the bulk tumor cell population is addicted, although a variety of distinct mechanisms are conceivable. Such heterogeneity is somewhat reminiscent of cancer stem cells, a more slowly growing subpopulation that also appears to be maintained at low frequency within a tumor cell population and that, furthermore, has been suggested to be resistant to various anti-cancer therapies (Dean et al. 2005). Hence, persisters and cancer stem cells may constitute a single entity, both comprised of cells exhibiting survival dependencies distinct from those of the bulk tumor population.

\section{Concluding remarks}

A rapidly growing body of evidence now supports a role for oncogene addiction in the sustained survival and proliferative capacity of many if not all tumor cells. Findings from cell culture models, genetically engineered mice, and clinical testing of targeted drugs all support a widespread role for oncogene addiction in tumor cell maintenance and response to acute oncoprotein inactivation. The precise mechanism by which cells acquire dependency on a single pathway or activated protein is 
not clear in most cases. Multiple theories have been put forth, including genetic streamlining, signaling network dysregulation, synthetic lethality, and oncogenic shock. However, experimental evidence to prove or disprove these models is generally lacking. Moreover, it is unlikely that a single mechanism accounts for the numerous reported experimental findings that appear to represent examples of oncogene dependency, and therefore, this still represents an important area for further investigation. Considering the potentially important therapeutic opportunity presented by oncogene addiction, there will undoubtedly be further mechanistic insights on the horizon.

\section{References}

Adachi, J., Ookawa, K., Shiseki, M., Okazaki, T., Tsuchida, S., Morishita, K., and Yokota, J. 1996. Induction of apoptosis but not G1 arrest by expression of the wild-type p53 gene in small cell lung carcinoma. Cell Growth Differ. 7: 879-886.

Akeno-Stuart, N., Croyle, M., Knauf, J.A., Malaguarnera, R., Vitagliano, D., Santoro, M., Stephan, C., Grosios, K., Wartmann, M., Cozens, R., et al. 2007. The RET kinase inhibitor NVP-AST487 blocks growth and calcitonin gene expression through distinct mechanisms in medullary thyroid cancer cells. Cancer Res. 67: 6956-6964.

Alarcon, R.M., Rupnow, B.A., Graeber, T.G., Knox, S.J., and Giaccia, A.J. 1996. Modulation of c-Myc activity and apoptosis in vivo. Cancer Res. 56: 4315-4319.

Arber, N. 1999. Janus faces of ras: Anti or pro-apoptotic? Apoptosis 4: 383-388.

Arbiser, J.L., Moses, M.A., Fernandez, C.A., Ghiso, N., Cao, Y., Klauber, N., Frank, D., Brownlee, M., Flynn, E., Parangi, S., et al. 1997. Oncogenic H-ras stimulates tumor angiogenesis by two distinct pathways. Proc. Natl. Acad. Sci. 94: 861-866.

Arvanitis, C. and Felsher, D.W. 2006. Conditional transgenic models define how MYC initiates and maintains tumorigenesis. Semin. Cancer Biol. 16: 313-317.

Balaban, N.Q., Merrin, J., Chait, R., Kowalik, L., and Leibler, S. 2004. Bacterial persistence as a phenotypic switch. Science 305: 1622-1625.

Beer, S., Zetterberg, A., Ihrie, R.A., McTaggart, R.A., Yang, Q., Bradon, N., Arvanitis, C., Attardi, L.D., Feng, S., Ruebner, B., et al. 2004. Developmental context determines latency of MYC-induced tumorigenesis. PLoS Biol. 2: e332. doi: 10.1371/journal.pbio.0020332.

Berger, M.S., Locher, G.W., Saurer, S., Gullick, W.J., Waterfield, M.D., Groner, B., and Hynes, N.E. 1988. Correlation of cerbB-2 gene amplification and protein expression in human breast carcinoma with nodal status and nuclear grading. Cancer Res. 48: 1238-1243.

Bernhard, E.J., Gruber, S.B., and Muschel, R.J. 1994. Direct evidence linking expression of matrix metalloproteinase $9(92-$ $\mathrm{kDa}$ gelatinase/collagenase) to the metastatic phenotype in transformed rat embryo cells. Proc. Natl. Acad. Sci. 91: 4293-4297.

Bissonnette, R.P., Echeverri, F., Mahboubi, A., and Green, D.R. 1992. Apoptotic cell death induced by c-myc is inhibited by bcl-2. Nature 359: 552-554.

Blaskovich, M.A., Lin, Q., Delarue, F.L., Sun, J., Park, H.S., Coppola, D., Hamilton, A.D., and Sebti, S.M. 2000. Design of GFB-111, a platelet-derived growth factor binding molecule with antiangiogenic and anticancer activity against human tumors in mice. Nat. Biotechnol. 18: 1065-1070.
Bouker, K.B., Skaar, T.C., Riggins, R.B., Harburger, D.S., Fernandez, D.R., Zwart, A., Wang, A., and Clarke, R. 2005. Interferon regulatory factor-1 (IRF-1) exhibits tumor suppressor activities in breast cancer associated with caspase activation and induction of apoptosis. Carcinogenesis 26: 15271535.

Boxer, R.B., Jang, J.W., Sintasath, L., and Chodosh, L.A. 2004. Lack of sustained regression of c-MYC-induced mammary adenocarcinomas following brief or prolonged MYC inactivation. Cancer Cell 6: 577-586.

Brysch, W., Magal, E., Louis, J.C., Kunst, M., Klinger, I., Schlingensiepen, R., and Schlingensiepen, K.H. 1994. Inhibition of p185c-erbB-2 proto-oncogene expression by antisense oligodeoxynucleotides down-regulates p185-associated tyrosinekinase activity and strongly inhibits mammary tumor-cell proliferation. Cancer Gene Ther. 1: 99-105.

Burgess, T., Coxon, A., Meyer, S., Sun, J., Rex, K., Tsuruda, T., Chen, Q., Ho, S.Y., Li, L., Kaufman, S., et al. 2006. Fully human monoclonal antibodies to hepatocyte growth factor with therapeutic potential against hepatocyte growth factor/c-Met-dependent human tumors. Cancer Res. 66: 1721-1729.

Bykov, V.J., Issaeva, N., Shilov, A., Hultcrantz, M., Pugacheva, E., Chumakov, P., Bergman, J., Wiman, K.G., and Selivanova, G. 2002. Restoration of the tumor suppressor function to mutant p53 by a low-molecular-weight compound. Nat. Med. 8: 282-288.

Cao, B., Su, Y., Oskarsson, M., Zhao, P., Kort, E.J., Fisher, R.J., Wang, L.M., and Vande Woude, G.F. 2001. Neutralizing monoclonal antibodies to hepatocyte growth factor/scatter factor (HGF/SF) display antitumor activity in animal models. Proc. Natl. Acad. Sci. 98: 7443-7448.

Carroll, M., Ohno-Jones, S., Tamura, S., Buchdunger, E., Zimmermann, J., Lydon, N.B., Gilliland, D.G., and Druker, B.J. 1997. CGP 57148, a tyrosine kinase inhibitor, inhibits the growth of cells expressing BCR-ABL, TEL-ABL, and TELPDGFR fusion proteins. Blood 90: 4947-4952.

Casanova, M.L., Larcher, F., Casanova, B., Murillas, R., Fernandez-Acenero, M.J., Villanueva, C., Martinez-Palacio, J., Ullrich, A., Conti, C.J., and Jorcano, J.L. 2002. A critical role for ras-mediated, epidermal growth factor receptor-dependent angiogenesis in mouse skin carcinogenesis. Cancer Res. 62: 3402-3407.

Chen, C.Y. and Faller, D.V. 1995. Direction of p21ras-generated signals towards cell growth or apoptosis is determined by protein kinase C and Bcl-2. Oncogene 11: 1487-1498.

Chen, C.Y., Liou, J., Forman, L.W., and Faller, D.V. 1998a. Correlation of genetic instability and apoptosis in the presence of oncogenic Ki-Ras. Cell Death Differ. 5: 984-995.

Chen, C.Y., Liou, J., Forman, L.W., and Faller, D.V. 1998b. Differential regulation of discrete apoptotic pathways by Ras. J. Biol. Chem. 273: 16700-16709.

Chen, J., Lee, B.H., Williams, I.R., Kutok, J.L., Mitsiades, C.S., Duclos, N., Cohen, S., Adelsperger, J., Okabe, R., Coburn, A., et al. 2005. FGFR3 as a therapeutic target of the small molecule inhibitor PKC412 in hematopoietic malignancies. Oncogene 24: 8259-8267.

Cheng, S.Y., Huang, H.J., Nagane, M., Ji, X.D., Wang, D., Shih, C.C., Arap, W., Huang, C.M., and Cavenee, W.K. 1996. Suppression of glioblastoma angiogenicity and tumorigenicity by inhibition of endogenous expression of vascular endothelial growth factor. Proc. Nat1. Acad. Sci. 93: 8502-8507.

Chesi, M., Nardini, E., Brents, L.A., Schrock, E., Ried, T., Kuehl, W.M., and Bergsagel, P.L. 1997. Frequent translocation $\mathrm{t}(4 ; 14)(\mathrm{p} 16.3 ; \mathrm{q} 32.3)$ in multiple myeloma is associated with increased expression and activating mutations of fibroblast 
growth factor receptor 3. Nat. Genet. 16: 260-264.

Chi, S., Kitanaka, C., Noguchi, K., Mochizuki, T., Nagashima, Y., Shirouzu, M., Fujita, H., Yoshida, M., Chen, W., Asai, A., et al. 1999. Oncogenic Ras triggers cell suicide through the activation of a caspase-independent cell death program in human cancer cells. Oncogene 18: 2281-2290.

Chin, L., Tam, A., Pomerantz, J., Wong, M., Holash, J., Bardeesy, N., Shen, Q., O'Hagan, R., Pantginis, J., Zhou, H., et al. 1999. Essential role for oncogenic Ras in tumour maintenance. Nature 400: 468-472.

Clark, W. and Gillespie, D.A. 1997. Transformation by v-Jun prevents cell cycle exit and promotes apoptosis in the absence of serum growth factors. Cell Growth Differ. 8: 371380.

Clarke, K., Smith, K., Gullick, W.J., and Harris, A.L. 2001. Mutant epidermal growth factor receptor enhances induction of vascular endothelial growth factor by hypoxia and insulinlike growth factor-1 via a PI3 kinase dependent pathway. $B r$. J. Cancer 84: 1322-1329.

Colomer, R., Lupu, R., Bacus, S.S., and Gelmann, E.P. 1994 erbB-2 antisense oligonucleotides inhibit the proliferation of breast carcinoma cells with erbB-2 oncogene amplification. Br. J. Cancer 70: 819-825.

Cory, S. and Adams, J.M. 2002. The Bcl2 family: Regulators of the cellular life-or-death switch. Nat. Rev. Cancer 2: 647656.

Danial, N.N. and Korsmeyer, S.J. 2004. Cell death: Critical control points. Cell 116: 205-219.

Daub, H., Specht, K., and Ullrich, A. 2004. Strategies to overcome resistance to targeted protein kinase inhibitors. Nat. Rev. Drug Discov. 3: 1001-1010.

Davies, H., Bignell, G.R., Cox, C., Stephens, P., Edkins, S., Clegg, S., Teague, J., Woffendin, H., Garnett, M.J., Bottomley, W., et al. 2002. Mutations of the BRAF gene in human cancer. Nature 417: 949-954.

Dean, M., Fojo, T., and Bates, S. 2005. Tumour stem cells and drug resistance. Nat. Rev. Cancer 5: 275-284.

Decaudin, D., de Cremoux, P., Sastre, X., Judde, J.G., Nemati, F., Tran-Perennou, C., Freneaux, P., Livartowski, A., Pouillart, P., and Poupon, M.F. 2005. In vivo efficacy of STI571 in xenografted human small cell lung cancer alone or combined with chemotherapy. Int. J. Cancer 113: 849-856.

Deininger, M.W., Goldman, J.M., Lydon, N., and Melo, J.V. 1997. The tyrosine kinase inhibitor CGP57148B selectively inhibits the growth of BCR-ABL-positive cells. Blood 90: 3691-3698.

Dhar, N. and McKinney, J.D. 2007. Microbial phenotypic heterogeneity and antibiotic tolerance. Curr. Opin. Microbiol. 10: $30-38$

Dong, G., Chen, Z., Li, Z.Y., Yeh, N.T., Bancroft, C.C., and Van Waes, C. 2001. Hepatocyte growth factor/scatter factor-induced activation of MEK and PI3K signal pathways contributes to expression of proangiogenic cytokines interleukin- 8 and vascular endothelial growth factor in head and neck squamous cell carcinoma. Cancer Res. 61: 5911-5918.

Drosten, M. and Putzer, B.M. 2006. Mechanisms of disease: Cancer targeting and the impact of oncogenic RET for medullary thyroid carcinoma therapy. Nat. Clin. Pract. Oncol. 3: 564-574.

Drosten, M., Frilling, A., Stiewe, T., and Putzer, B.M. 2002. A new therapeutic approach in medullary thyroid cancer treatment: Inhibition of oncogenic RET signaling by adenoviral vector-mediated expression of a dominant-negative RET mutant. Surgery 132: 991-997.

Drosten, M., Stiewe, T., and Putzer, B.M. 2003. Antitumor capacity of a dominant-negative RET proto-oncogene mutant in a medullary thyroid carcinoma model. Hum. Gene Ther. 14: 971-982.

Druker, B.J., Tamura, S., Buchdunger, E., Ohno, S., Segal, G.M., Fanning, S., Zimmermann, J., and Lydon, N.B. 1996. Effects of a selective inhibitor of the Abl tyrosine kinase on the growth of Bcr-Abl positive cells. Nat. Med. 2: 561-566.

Druker, B.J., Talpaz, M., Resta, D.J., Peng, B., Buchdunger, E., Ford, J.M., Lydon, N.B., Kantarjian, H., Capdeville, R., OhnoJones, S., et al. 2001. Efficacy and safety of a specific inhibitor of the BCR-ABL tyrosine kinase in chronic myeloid leukemia. N. Engl. J. Med. 344: 1031-1037.

Emanuel, S., Rugg, C.A., Gruninger, R.H., Lin, R., FuentesPesquera, A., Connolly, P.J., Wetter, S.K., Hollister, B., Kruger, W.W., Napier, C., et al. 2005. The in vitro and in vivo effects of JNJ-7706621: A dual inhibitor of cyclin-dependent kinases and aurora kinases. Cancer Res. 65: 9038-9046.

Engelman, J.A., Zejnullahu, K., Mitsudomi, T., Song, Y., Hyland, C., Park, J.O., Lindeman, N., Gale, C.M., Zhao, X., Christensen, J., et al. 2007. MET amplification leads to gefitinib resistance in lung cancer by activating ERBB3 signaling. Science 316: 1039-1043.

Esquela-Kerscher, A. and Slack, F.J. 2006. Oncomirs-microRNAs with a role in cancer. Nat. Rev. Cancer 6: 259-269.

Evan, G. and Littlewood, T. 1998. A matter of life and cell death. Science 281: 1317-1322.

Evan, G.I. and Vousden, K.H. 2001. Proliferation, cell cycle and apoptosis in cancer. Nature 411: 342-348.

Evan, G.I., Wyllie, A.H., Gilbert, C.S., Littlewood, T.D., Land, H., Brooks, M., Waters, C.M., Penn, L.Z., and Hancock, D.C. 1992. Induction of apoptosis in fibroblasts by c-myc protein. Cell 69: 119-128.

Evan, G., Harrington, E., Fanidi, A., Land, H., Amati, B., and Bennett, M. 1994. Integrated control of cell proliferation and cell death by the c-myc oncogene. Philos. Trans. R. Soc. Lond. B Biol. Sci. 345: 269-275.

Fabbri, M., Iliopoulos, D., Trapasso, F., Aqeilan, R.I., Cimmino, A., Zanesi, N., Yendamuri, S., Han, S.Y., Amadori, D., Huebner, K., et al. 2005. WWOX gene restoration prevents lung cancer growth in vitro and in vivo. Proc. Natl. Acad. Sci. 102: 15611-15616.

Fanton, C.P., McMahon, M., and Pieper, R.O. 2001. Dual growth arrest pathways in astrocytes and astrocytic tumors in response to Raf-1 activation. J. Biol. Chem. 276: 1887118877.

Felsher, D.W. and Bishop, J.M. 1999. Reversible tumorigenesis by MYC in hematopoietic lineages. Mol. Cell 4: 199-207.

Ferbeyre, G., de Stanchina, E., Lin, A.W., Querido, E., McCurrach, M.E., Hannon, G.J., and Lowe, S.W. 2002. Oncogenic ras and p53 cooperate to induce cellular senescence. Mol. Cell. Biol. 22: 3497-3508.

Fisher, G.H., Wellen, S.L., Klimstra, D., Lenczowski, J.M., Tichelaar, J.W., Lizak, M.J., Whitsett, J.A., Koretsky, A., and Varmus, H.E. 2001. Induction and apoptotic regression of lung adenocarcinomas by regulation of a K-Ras transgene in the presence and absence of tumor suppressor genes. Genes \& Dev. 15: 3249-3262.

Fleming, T.P., Saxena, A., Clark, W.C., Robertson, J.T., Oldfield, E.H., Aaronson, S.A., and Ali, I.U. 1992. Amplification and/or overexpression of platelet-derived growth factor receptors and epidermal growth factor receptor in human glial tumors. Cancer Res. 52: 4550-4553.

Folkman, J. and Hanahan, D. 1991. Switch to the angiogenic phenotype during tumorigenesis. Princess Takamatsu Symp. 22: 339-347.

Frisch, S.M., Vuori, K., Kelaita, D., and Sicks, S. 1996. A role for Jun-N-terminal kinase in anoikis; suppression by bcl-2 and 
crmA. J. Cell Biol. 135: 1377-1382.

Galkin, A.V., Melnick, J.S., Kim, S., Hood, T.L., Li, N., Li, L., Xia, G., Steensma, R., Chopiuk, G., Jiang, J., et al. 2007. Identification of NVP-TAE684, a potent, selective, and efficacious inhibitor of NPM-ALK. Proc. Natl. Acad. Sci. 104: 270-275.

Gallagher, A.P., Burnett, A.K., Bowen, D.T., and Darley, R.L. 1998. Mutant RAS selectively promotes sensitivity of myeloid leukemia cells to apoptosis by a protein kinase C-dependent process. Cancer Res. 58: 2029-2035.

Garton, A.J., Crew, A.P., Franklin, M., Cooke, A.R., Wynne, G.M., Castaldo, L., Kahler, J., Winski, S.L., Franks, A., Brown, E.N., et al. 2006. OSI-930: A novel selective inhibitor of Kit and kinase insert domain receptor tyrosine kinases with antitumor activity in mouse xenograft models. Cancer Res. 66: 1015-1024.

Golas, J.M., Arndt, K., Etienne, C., Lucas, J., Nardin, D., Gibbons, J., Frost, P., Ye, F., Boschelli, D.H., and Boschelli, F. 2003. SKI-606, a 4-anilino-3-quinolinecarbonitrile dual inhibitor of Src and Abl kinases, is a potent antiproliferative agent against chronic myelogenous leukemia cells in culture and causes regression of K562 xenografts in nude mice. Cancer Res. 63: 375-381.

Goldman, C.K., Kim, J., Wong, W.L., King, V., Brock, T., and Gillespie, G.Y. 1993. Epidermal growth factor stimulates vascular endothelial growth factor production by human malignant glioma cells: A model of glioblastoma multiforme pathophysiology. Mol. Biol. Cell 4: 121-133.

Gomez-Manzano, C., Fueyo, J., Kyritsis, A.P., Steck, P.A., Roth, J.A., McDonnell, T.J., Steck, K.D., Levin, V.A., and Yung, W.K. 1996. Adenovirus-mediated transfer of the p53 gene produces rapid and generalized death of human glioma cells via apoptosis. Cancer Res. 56: 694-699.

Grand, E.K., Chase, A.J., Heath, C., Rahemtulla, A., and Cross, N.C. 2004. Targeting FGFR3 in multiple myeloma: Inhibition of $\mathrm{t}(4 ; 14)$-positive cells by SU5402 and PD173074. Leukemia 18: 962-966.

Green, D.R. and Evan, G.I. 2002. A matter of life and death. Cancer Cell 1: 19-30.

Groth, A., Weber, J.D., Willumsen, B.M., Sherr, C.J., and Roussel, M.F. 2000. Oncogenic Ras induces p19ARF and growth arrest in mouse embryo fibroblasts lacking p21Cip1 and p27Kip1 without activating cyclin D-dependent kinases. J. Biol. Chem. 275: 27473-27480.

Guerin, M., Barrois, M., Terrier, M.J., Spielmann, M., and Riou, G. 1988. Overexpression of either c-myc or c-erbB-2/neu proto-oncogenes in human breast carcinomas: Correlation with poor prognosis. Oncogene Res. 3: 21-31.

Halatsch, M.E., Schmidt, U., Botefur, I.C., Holland, J.F., and Ohnuma, T. 2000. Marked inhibition of glioblastoma target cell tumorigenicity in vitro by retrovirus-mediated transfer of a hairpin ribozyme against deletion-mutant epidermal growth factor receptor messenger RNA. J. Neurosurg. 92: 297-305.

Hanahan, D. and Weinberg, R.A. 2000. The hallmarks of cancer. Cell 100: $57-70$.

Harrington, E.A., Bennett, M.R., Fanidi, A., and Evan, G.I. 1994a. c-Myc-induced apoptosis in fibroblasts is inhibited by specific cytokines. EMBO J. 13: 3286-3295.

Harrington, E.A., Fanidi, A., and Evan, G.I. 1994b. Oncogenes and cell death. Curr. Opin. Genet. Dev. 4: 120-129.

Harrington, E.A., Bebbington, D., Moore, J., Rasmussen, R.K., Ajose-Adeogun, A.O., Nakayama, T., Graham, J.A., Demur, C., Hercend, T., Diu-Hercend, A., et al. 2004. VX-680, a potent and selective small-molecule inhibitor of the Aurora kinases, suppresses tumor growth in vivo. Nat. Med. 10:
262-267.

Hata, T., Furukawa, T., Sunamura, M., Egawa, S., Motoi, F., Ohmura, N., Marumoto, T., Saya, H., and Horii, A. 2005 RNA interference targeting aurora kinase a suppresses tumor growth and enhances the taxane chemosensitivity in human pancreatic cancer cells. Cancer Res. 65: 2899-2905.

Heinrich, M.C., Corless, C.L., Demetri, G.D., Blanke, C.D., von Mehren, M., Joensuu, H., McGreevey, L.S., Chen, C.J., Van den Abbeele, A.D., Druker, B.J., et al. 2003a. Kinase mutations and imatinib response in patients with metastatic gastrointestinal stromal tumor. J. Clin. Oncol. 21: 4342-4349.

Heinrich, M.C., Corless, C.L., Duensing, A., McGreevey, L., Chen, C.J., Joseph, N., Singer, S., Griffith, D.J., Haley, A., Town, A., et al. 2003b. PDGFRA activating mutations in gastrointestinal stromal tumors. Science 299: 708-710.

Hiebert, S.W., Packham, G., Strom, D.K., Haffner, R., Oren, M., Zambetti, G., and Cleveland, J.L. 1995. E2F-1:DP-1 induces p53 and overrides survival factors to trigger apoptosis. Mol. Cell. Biol. 15: 6864-6874.

Hietanen, S., Lain, S., Krausz, E., Blattner, C., and Lane, D.P. 2000. Activation of p53 in cervical carcinoma cells by small molecules. Proc. Nat1. Acad. Sci. 97: 8501-8506.

Hingorani, S.R., Jacobetz, M.A., Robertson, G.P., Herlyn, M., and Tuveson, D.A. 2003. Suppression of BRAF(V599E) in human melanoma abrogates transformation. Cancer Res. 63: 5198-5202.

Hirota, S., Isozaki, K., Moriyama, Y., Hashimoto, K., Nishida, T., Ishiguro, S., Kawano, K., Hanada, M., Kurata, A., Takeda, M., et al. 1998. Gain-of-function mutations of c-kit in human gastrointestinal stromal tumors. Science 279: 577-580.

Hsu, F.Y., Zhao, Y., Anderson, W.F., and Johnston, P.B. 2007. Downregulation of NPM-ALK by siRNA causes anaplastic large cell lymphoma cell growth inhibition and augments the anti cancer effects of chemotherapy in vitro. Cancer Invest. 25: 240-248.

Hua, J. and Muschel, R.J. 1996. Inhibition of matrix metalloproteinase 9 expression by a ribozyme blocks metastasis in a rat sarcoma model system. Cancer Res. 56: 5279-5284.

Hudis, C.A. 2007. Trastuzumab-Mechanism of action and use in clinical practice. N. Engl. J. Med. 357: 39-51.

Hudziak, R.M., Lewis, G.D., Winget, M., Fendly, B.M., Shepard, H.M., and Ullrich, A. 1989. p185HER2 monoclonal antibody has antiproliferative effects in vitro and sensitizes human breast tumor cells to tumor necrosis factor. Mol. Cell. Biol. 9: $1165-1172$.

Hueber, A.O. and Evan, G.I. 1998. Traps to catch unwary oncogenes. Trends Genet. 14: 364-367.

Iliopoulos, D., Fabbri, M., Druck, T., Qin, H.R., Han, S.Y., and Huebner, K. 2007. Inhibition of breast cancer cell growth in vitro and in vivo: Effect of restoration of Wwox expression. Clin. Cancer Res. 13: 268-274.

Irwin, M., Marin, M.C., Phillips, A.C., Seelan, R.S., Smith, D.I., Liu, W., Flores, E.R., Tsai, K.Y., Jacks, T., Vousden, K.H., et al. 2000. Role for the p53 homologue p73 in E2F-1-induced apoptosis. Nature 407: 645-648.

Jain, M., Arvanitis, C., Chu, K., Dewey, W., Leonhardt, E., Trinh, M., Sundberg, C.D., Bishop, J.M., and Felsher, D.W. 2002. Sustained loss of a neoplastic phenotype by brief inactivation of MYC. Science 297: 102-104.

Ji, H., Li, D., Chen, L., Shimamura, T., Kobayashi, S., McNamara, K., Mahmood, U., Mitchell, A., Sun, Y., Al-Hashem, R., et al. 2006a. The impact of human EGFR kinase domain mutations on lung tumorigenesis and in vivo sensitivity to EGFR-targeted therapies. Cancer Cell 9: 485-495.

Ji, H., Zhao, X., Yuza, Y., Shimamura, T., Li, D., Protopopov, A., Jung, B.L., McNamara, K., Xia, H., Glatt, K.A., et al. 2006b. 
Epidermal growth factor receptor variant III mutations in lung tumorigenesis and sensitivity to tyrosine kinase inhibitors. Proc. Natl. Acad. Sci. 103: 7817-7822.

Johnson, D., Agochiya, M., Samejima, K., Earnshaw, W., Frame, M., and Wyke, J. 2000. Regulation of both apoptosis and cell survival by the v-Src oncoprotein. Cell Death Differ. 7: 685696.

Kaelin Jr., W.G. 2005. The concept of synthetic lethality in the context of anticancer therapy. Nat. Rev. Cancer 5: 689-698.

$\mathrm{Kamb}$, A. 2003. Consequences of nonadaptive alterations in cancer. Mol. Biol. Cell 14: 2201-2205.

Karasarides, M., Chiloeches, A., Hayward, R., Niculescu-Duvaz, D., Scanlon, I., Friedlos, F., Ogilvie, L., Hedley, D., Martin, J., Marshall, C.J., et al. 2004. B-RAF is a therapeutic target in melanoma. Oncogene 23: 6292-6298.

Kauffmann-Zeh, A., Rodriguez-Viciana, P., Ulrich, E., Gilbert, C., Coffer, P., Downward, J., and Evan, G. 1997. Suppression of c-Myc-induced apoptosis by Ras signalling through $\mathrm{PI}(3) \mathrm{K}$ and PKB. Nature 385: 544-548.

Kerbel, R.S. 2006. Antiangiogenic therapy: A universal chemosensitization strategy for cancer? Science 312: 1171-1175.

Kilic, T., Alberta, J.A., Zdunek, P.R., Acar, M., Iannarelli, P., O'Reilly, T., Buchdunger, E., Black, P.M., and Stiles, C.D. 2000. Intracranial inhibition of platelet-derived growth factor-mediated glioblastoma cell growth by an orally active kinase inhibitor of the 2-phenylaminopyrimidine class. Cancer Res. 60: 5143-5150.

Kim, K.J., Li, B., Winer, J., Armanini, M., Gillett, N., Phillips, H.S., and Ferrara, N. 1993. Inhibition of vascular endothelial growth factor-induced angiogenesis suppresses tumour growth in vivo. Nature 362: 841-844.

Kim, P.K., Armstrong, M., Liu, Y., Yan, P., Bucher, B., Zuckerbraun, B.S., Gambotto, A., Billiar, T.R., and Yim, J.H. 2004. IRF-1 expression induces apoptosis and inhibits tumor growth in mouse mammary cancer cells in vitro and in vivo. Oncogene 23: 1125-1135.

Kinzler, K.W. and Vogelstein, B. 1996. Lessons from hereditary colorectal cancer. Cell 87: 159-170.

Kohl, N.E., Wilson, F.R., Mosser, S.D., Giuliani, E., deSolms, S.J., Conner, M.W., Anthony, N.J., Holtz, W.J., Gomez, R.P., Lee, T.J., et al. 1994. Protein farnesyltransferase inhibitors block the growth of ras-dependent tumors in nude mice. Proc. Natl. Acad. Sci. 91: 9141-9145.

Kondo, S., Asano, M., and Suzuki, H. 1993. Significance of vascular endothelial growth factor/vascular permeability factor for solid tumor growth, and its inhibition by the antibody. Biochem. Biophys. Res. Commun. 194: 1234-1241.

Kondo, T., Ezzat, S., and Asa, S.L. 2006. Pathogenetic mechanisms in thyroid follicular-cell neoplasia. Nat. Rev. Cancer 6: 292-306.

Kowalik, T.F., DeGregori, J., Schwarz, J.K., and Nevins, J.R. 1995. E2F1 overexpression in quiescent fibroblasts leads to induction of cellular DNA synthesis and apoptosis. J. Virol. 69: $2491-2500$

Kowalik, T.F., DeGregori, J., Leone, G., Jakoi, L., and Nevins, J.R. 1998. E2F1-specific induction of apoptosis and p53 accumulation, which is blocked by Mdm2. Cell Growth Differ. 9: $113-118$

Krystal, G.W., Honsawek, S., Litz, J., and Buchdunger, E. 2000. The selective tyrosine kinase inhibitor STI571 inhibits small cell lung cancer growth. Clin. Cancer Res. 6: 3319-3326.

Kurata, T., Tamura, K., Kaneda, H., Nogami, T., Uejima, H., Asai Go, G., Nakagawa, K., and Fukuoka, M. 2004. Effect of re-treatment with gefitinib ('Iressa,' ZD1839) after acquisition of resistance. Ann. Oncol. 15: 173-174.

Laird, A.D., Vajkoczy, P., Shawver, L.K., Thurnher, A., Liang,
C., Mohammadi, M., Schlessinger, J., Ullrich, A., Hubbard, S.R., Blake, R.A., et al. 2000. SU6668 is a potent antiangiogenic and antitumor agent that induces regression of established tumors. Cancer Res. 60: 4152-4160.

Lewis, K. 2007. Persister cells, dormancy and infectious disease. Nat. Rev. Microbiol. 5: 48-56.

Li, F., Ambrosini, G., Chu, E.Y., Plescia, J., Tognin, S., Marchisio, P.C., and Altieri, D.C. 1998. Control of apoptosis and mitotic spindle checkpoint by survivin. Nature 396: 580 584.

Li, F., Ackermann, E.J., Bennett, C.F., Rothermel, A.L., Plescia, J., Tognin, S., Villa, A., Marchisio, P.C., and Altieri, D.C. 1999. Pleiotropic cell-division defects and apoptosis induced by interference with survivin function. Nat. Cell Biol. 1: 461-466.

Liao, D. and Johnson, R.S. 2007. Hypoxia: A key regulator of angiogenesis in cancer. Cancer Metastasis Rev. 26: 281-290.

Libermann, T.A., Nusbaum, H.R., Razon, N., Kris, R., Lax, I., Soreq, H., Whittle, N., Waterfield, M.D., Ullrich, A., and Schlessinger, J. 1985. Amplification, enhanced expression and possible rearrangement of EGF receptor gene in primary human brain tumours of glial origin. Nature 313: 144-147.

Liu, M., Bryant, M.S., Chen, J., Lee, S., Yaremko, B., Lipari, P., Malkowski, M., Ferrari, E., Nielsen, L., Prioli, N., et al. 1998. Antitumor activity of SCH 66336, an orally bioavailable tricyclic inhibitor of farnesyl protein transferase, in human tumor xenograft models and wap-ras transgenic mice. Cancer Res. 58: 4947-4956.

Liu, Y., Hong, Y., Androphy, E.J., and Chen, J.J. 2000. Rb-independent induction of apoptosis by bovine papillomavirus type $1 \mathrm{E} 7$ in response to tumor necrosis factor $\alpha$. J. Biol. Chem. 275: 30894-30900.

Loke, S.L., Stein, C., Zhang, X., Avigan, M., Cohen, J., and Neckers, L.M. 1988. Delivery of c-myc antisense phosphorothioate oligodeoxynucleotides to hematopoietic cells in culture by liposome fusion: Specific reduction in c-myc protein expression correlates with inhibition of cell growth and DNA synthesis. Curr. Top. Microbiol. Immunol. 141: 282289 .

Loughran, O. and La Thangue, N.B. 2000. Apoptotic and growth-promoting activity of E2F modulated by MDM2. Mol. Cell. Biol. 20: 2186-2197.

Lowe, S.W., Cepero, E., and Evan, G. 2004. Intrinsic tumour suppression. Nature 432: 307-315.

Luwor, R.B., Johns, T.G., Murone, C., Huang, H.J., Cavenee, W.K., Ritter, G., Old, L.J., Burgess, A.W., and Scott, A.M. 2001. Monoclonal antibody 806 inhibits the growth of tumor xenografts expressing either the de2-7 or amplified epidermal growth factor receptor (EGFR) but not wild-type EGFR. Cancer Res. 61: 5355-5361.

Lynch, T.J., Bell, D.W., Sordella, R., Gurubhagavatula, S., Okimoto, R.A., Brannigan, B.W., Harris, P.L., Haserlat, S.M., Supko, J.G., Haluska, F.G., et al. 2004. Activating mutations in the epidermal growth factor receptor underlying responsiveness of non-small-cell lung cancer to gefitinib. N. Engl. J. Med. 350: 2129-2139.

Ma, P.C., Jagadeeswaran, R., Jagadeesh, S., Tretiakova, M.S., Nallasura, V., Fox, E.A., Hansen, M., Schaefer, E., Naoki, K., Lader, A., et al. 2005. Functional expression and mutations of c-Met and its therapeutic inhibition with SU11274 and small interfering RNA in non-small cell lung cancer. Cancer Res. 65: 1479-1488.

MacLaren, A., Clark, W., and Gillespie, D.A. 2000. v-Jun sensitizes cells to apoptosis by a mechanism involving mitochondrial cytochrome C release. Oncogene 19: 5906-5918.

Maity, A., Pore, N., Lee, J., Solomon, D., and O'Rourke, D.M. 
2000. Epidermal growth factor receptor transcriptionally upregulates vascular endothelial growth factor expression in human glioblastoma cells via a pathway involving phosphatidylinositol 3 '-kinase and distinct from that induced by hypoxia. Cancer Res. 60: 5879-5886.

Manfredi, M.G., Ecsedy, J.A., Meetze, K.A., Balani, S.K., Burenkova, O., Chen, W., Galvin, K.M., Hoar, K.M., Huck, J.J., LeRoy, P.J., et al. 2007. Antitumor activity of MLN8054, an orally active small-molecule inhibitor of Aurora A kinase. Proc. Natl. Acad. Sci. 104: 4106-4111.

Martins, C.P., Brown-Swigart, L., and Evan, G.I. 2006. Modeling the therapeutic efficacy of p53 restoration in tumors. Cell 127: $1323-1334$.

Marumoto, T., Zhang, D., and Saya, H. 2005. Aurora-A-A guardian of poles. Nat. Rev. Cancer 5: 42-50.

Matsubara, H., Takeuchi, T., Nishikawa, E., Yanagisawa, K., Hayashita, Y., Ebi, H., Yamada, H., Suzuki, M., Nagino, M., Nimura, Y., et al. 2007. Apoptosis induction by antisense oligonucleotides against miR-17-5p and miR-20a in lung cancers overexpressing miR-17-92. Oncogene 26: 60996105.

Mayo, M.W., Wang, C.Y., Cogswell, P.C., Rogers-Graham, K.S., Lowe, S.W., Der, C.J., and Baldwin Jr., A.S. 1997. Requirement of NF- $\mathrm{KB}$ activation to suppress p53-independent apoptosis induced by oncogenic Ras. Science 278: 1812-1815.

McCormick, F. 2001. Cancer gene therapy: Fringe or cutting edge? Nat. Rev. Cancer 1: 130-141.

Mills, G.B., Lu, Y., and Kohn, E.C. 2001. Linking molecular therapeutics to molecular diagnostics: Inhibition of the FRAP/RAFT/TOR component of the PI3K pathway preferentially blocks PTEN mutant cells in vitro and in vivo. Proc. Natl. Acad. Sci. 98: 10031-10033.

Miranda, E.I., Santana, C., Rojas, E., Hernandez, S., OstroskyWegman, P., and Garcia-Carranca, A. 1996. Induced mitotic death of HeLa cells by abnormal expression of c-H-ras. Mutat. Res. 349: 173-182.

Mologni, L., Sala, E., Cazzaniga, S., Rostagno, R., Kuoni, T., Puttini, M., Bain, J., Cleris, L., Redaelli, S., Riva, B., et al. 2006. Inhibition of RET tyrosine kinase by SU5416. J. Mol. Endocrinol. 37: 199-212.

Moriyama, T., Kataoka, H., Hamasuna, R., Yokogami, K., Uehara, H., Kawano, H., Goya, T., Tsubouchi, H., Koono, M., and Wakisaka, S. 1998. Up-regulation of vascular endothelial growth factor induced by hepatocyte growth factor/scatter factor stimulation in human glioma cells. Biochem. Biophys. Res. Commun. 249: 73-77.

Morris, S.W., Kirstein, M.N., Valentine, M.B., Dittmer, K.G., Shapiro, D.N., Saltman, D.L., and Look, A.T. 1994. Fusion of a kinase gene, ALK, to a nucleolar protein gene, NPM, in non-Hodgkin's lymphoma. Science 263: 1281-1284.

Mukhopadhyay, T., Tainsky, M., Cavender, A.C., and Roth, J.A. 1991. Specific inhibition of K-ras expression and tumorigenicity of lung cancer cells by antisense RNA. Cancer Res. 51: 1744-1748.

Mulloy, R., Ferrand, A., Kim, Y., Sordella, R., Bell, D.W., Haber, D.A., Anderson, K.S., and Settleman, J. 2007. Epidermal growth factor receptor mutants from human lung cancers exhibit enhanced catalytic activity and increased sensitivity to gefitinib. Cancer Res. 67: 2325-2330.

Nishikawa, R., Ji, X.D., Harmon, R.C., Lazar, C.S., Gill, G.N., Cavenee, W.K., and Huang, H.J. 1994. A mutant epidermal growth factor receptor common in human glioma confers enhanced tumorigenicity. Proc. Nat1. Acad. Sci. 91: 77277731.

Nister, M., Claesson-Welsh, L., Eriksson, A., Heldin, C.H., and Westermark, B. 1991. Differential expression of platelet-de- rived growth factor receptors in human malignant glioma cell lines. J. Biol. Chem. 266: 16755-16763.

Norton, J.D. and Atherton, G.T. 1998. Coupling of cell growth control and apoptosis functions of Id proteins. Mol. Cell. Biol. 18: 2371-2381.

Ohnishi, Y., Nakamura, H., Yoshimura, M., Tokuda, Y., Iwasawa, M., Ueyama, Y., Tamaoki, N., and Shimamura, K. 1995. Prolonged survival of mice with human gastric cancer treated with an anti-c-ErbB-2 monoclonal antibody. Br. $J$. Cancer 71: 969-973.

Paez, J.G., Janne, P.A., Lee, J.C., Tracy, S., Greulich, H., Gabriel, S., Herman, P., Kaye, F.J., Lindeman, N., Boggon, T.J., et al. 2004. EGFR mutations in lung cancer: Correlation with clinical response to gefitinib therapy. Science 304: 1497-1500.

Pao, W., Miller, V., Zakowski, M., Doherty, J., Politi, K., Sarkaria, I., Singh, B., Heelan, R., Rusch, V., Fulton, L., et al. 2004. EGF receptor gene mutations are common in lung cancers from 'never smokers' and are associated with sensitivity of tumors to gefitinib and erlotinib. Proc. Natl. Acad. Sci. 101: 13306-13311.

Pao, W., Miller, V.A., Politi, K.A., Riely, G.J., Somwar, R., Zakowski, M.F., Kris, M.G., and Varmus, H. 2005. Acquired resistance of lung adenocarcinomas to gefitinib or erlotinib is associated with a second mutation in the EGFR kinase domain. PLoS Med 2: e73. doi: 10.1371/journal.pmed. 0020073.

Parthasarathy, R., Cote, G.J., and Gagel, R.F. 1999. Hammerhead ribozyme-mediated inactivation of mutant RET in medullary thyroid carcinoma. Cancer Res. 59: 3911-3914.

Paterson, J.L., Li, Z., Wen, X.Y., Masih-Khan, E., Chang, H., Pollett, J.B., Trudel, S., and Stewart, A.K. 2004. Preclinical studies of fibroblast growth factor receptor 3 as a therapeutic target in multiple myeloma. Br. J. Haematol. 124: 595-603.

Petit, A.M., Rak, J., Hung, M.C., Rockwell, P., Goldstein, N., Fendly, B., and Kerbel, R.S. 1997. Neutralizing antibodies against epidermal growth factor and ErbB-2/neu receptor tyrosine kinases down-regulate vascular endothelial growth factor production by tumor cells in vitro and in vivo: Angiogenic implications for signal transduction therapy of solid tumors. Am. J. Pathol. 151: 1523-1530.

Petrangolini, G., Cuccuru, G., Lanzi, C., Tortoreto, M., Belluco, S., Pratesi, G., Cassinelli, G., and Zunino, F. 2006. Apoptotic cell death induction and angiogenesis inhibition in large established medullary thyroid carcinoma xenografts by Ret inhibitor RPI-1. Biochem. Pharmacol. 72: 405-414.

Petrocca, F., Iliopoulos, D., Qin, H.R., Nicoloso, M.S., Yendamuri, S., Wojcik, S.E., Shimizu, M., Di Leva, G., Vecchione, A., Trapasso, F., et al. 2006. Alterations of the tumor suppressor gene ARLTS1 in ovarian cancer. Cancer Res. 66: 1028710291.

Pichiorri, F., Trapasso, F., Palumbo, T., Aqeilan, R.I., Drusco, A., Blaser, B.W., Iliopoulos, D., Caligiuri, M.A., Huebner, K., and Croce, C.M. 2006. Preclinical assessment of FHIT gene replacement therapy in human leukemia using a chimeric adenovirus, Ad5/F35. Clin. Cancer Res. 12: 3494-3501.

Piva, R., Chiarle, R., Manazza, A.D., Taulli, R., Simmons, W., Ambrogio, C., D'Escamard, V., Pellegrino, E., Ponzetto, C., Palestro, G., et al. 2006. Ablation of oncogenic ALK is a viable therapeutic approach for anaplastic large-cell lymphomas. Blood 107: 689-697.

Politi, K., Zakowski, M.F., Fan, P.D., Schonfeld, E.A., Pao, W., and Varmus, H.E. 2006. Lung adenocarcinomas induced in mice by mutant EGF receptors found in human lung cancers respond to a tyrosine kinase inhibitor or to down-regulation of the receptors. Genes \& Dev. 20: 1496-1510. 
Prenen, H., Cools, J., Mentens, N., Folens, C., Sciot, R., Schoffski, P., Van Oosterom, A., Marynen, P., and Debiec-Rychter, M. 2006. Efficacy of the kinase inhibitor SU11248 against gastrointestinal stromal tumor mutants refractory to imatinib mesylate. Clin. Cancer Res. 12: 2622-2627.

Preston, G.A., Lyon, T.T., Yin, Y., Lang, J.E., Solomon, G., Annab, L., Srinivasan, D.G., Alcorta, D.A., and Barrett, J.C. 1996. Induction of apoptosis by c-Fos protein. Mol. Cell. Biol. 16: 211-218.

Preston, G.A., Srinivasan, D., and Barrett, J.C. 2000. Apoptotic response to growth factor deprivation involves cooperative interactions between c-Fos and p300. Cell Death Differ. 7: 215-226.

Puri, N., Khramtsov, A., Ahmed, S., Nallasura, V., Hetzel, J.T., Jagadeeswaran, R., Karczmar, G., and Salgia, R. 2007. A selective small molecule inhibitor of c-Met, PHA665752, inhibits tumorigenicity and angiogenesis in mouse lung cancer xenografts. Cancer Res. 67: 3529-3534.

Qanungo, S., Haldar, S., and Basu, A. 2003. Restoration of silenced Peutz-Jeghers syndrome gene, LKB1, induces apoptosis in pancreatic carcinoma cells. Neoplasia 5: 367-374.

Qin, X.Q., Livingston, D.M., Kaelin Jr., W.G., and Adams, P.D. 1994. Deregulated transcription factor E2F-1 expression leads to S-phase entry and p53-mediated apoptosis. Proc. Natl. Acad. Sci. 91: 10918-10922.

Qin, H.R., Iliopoulos, D., Semba, S., Fabbri, M., Druck, T., Volinia, S., Croce, C.M., Morrison, C.D., Klein, R.D., and Huebner, K. 2006. A role for the WWOX gene in prostate cancer. Cancer Res. 66: 6477-6481.

Rabindran, S.K., Discafani, C.M., Rosfjord, E.C., Baxter, M., Floyd, M.B., Golas, J., Hallett, W.A., Johnson, B.D., Nilakantan, R., Overbeek, E., et al. 2004. Antitumor activity of HKI272 , an orally active, irreversible inhibitor of the HER-2 tyrosine kinase. Cancer Res. 64: 3958-3965.

Rak, J., Filmus, J., Finkenzeller, G., Grugel, S., Marme, D., and Kerbel, R.S. 1995a. Oncogenes as inducers of tumor angiogenesis. Cancer Metastasis Rev. 14: 263-277.

Rak, J., Mitsuhashi, Y., Erdos, V., Huang, S.N., Filmus, J., and Kerbel, R.S. 1995b. Massive programmed cell death in intestinal epithelial cells induced by three-dimensional growth conditions: Suppression by mutant c-H-ras oncogene expression. J. Cell Biol. 131: 1587-1598.

Reddy, A. and Kaelin Jr., W.G. 2002. Using cancer genetics to guide the selection of anticancer drug targets. Curr. Opin. Pharmacol. 2: 366-373.

Roz, L., Gramegna, M., Ishii, H., Croce, C.M., and Sozzi, G. 2002. Restoration of fragile histidine triad (FHIT) expression induces apoptosis and suppresses tumorigenicity in lung and cervical cancer cell lines. Proc. Natl. Acad. Sci. 99: 36153620.

Saleh, M., Stacker, S.A., and Wilks, A.F. 1996. Inhibition of growth of C6 glioma cells in vivo by expression of antisense vascular endothelial growth factor sequence. Cancer Res. 56: 393-401.

Salvesen, G.S. and Duckett, C.S. 2002. IAP proteins: Blocking the road to death's door. Nat. Rev. Mol. Cell Biol. 3: 401-410.

Sarti, M., Sevignani, C., Calin, G.A., Aqeilan, R., Shimizu, M., Pentimalli, F., Picchio, M.C., Godwin, A., Rosenberg, A., Drusco, A., et al. 2005. Adenoviral transduction of TESTIN gene into breast and uterine cancer cell lines promotes apoptosis and tumor reduction in vivo. Clin. Cancer Res. 11: 806-813.

Sattler, M., Pride, Y.B., Ma, P., Gramlich, J.L., Chu, S.C., Quinnan, L.A., Shirazian, S., Liang, C., Podar, K., Christensen, J.G., et al. 2003. A novel small molecule met inhibitor induces apoptosis in cells transformed by the oncogenic TPR-
MET tyrosine kinase. Cancer Res. 63: 5462-5469.

Schubbert, S., Shannon, K., and Bollag, G. 2007. Hyperactive Ras in developmental disorders and cancer. Nat. Rev. Cancer 7: 295-308.

Serrano, M., Lin, A.W., McCurrach, M.E., Beach, D., and Lowe, S.W. 1997. Oncogenic ras provokes premature cell senescence associated with accumulation of p53 and p16INK4a. Cell 88: 593-602.

Sevignani, C., Calin, G.A., Cesari, R., Sarti, M., Ishii, H., Yendamuri, S., Vecchione, A., Trapasso, F., and Croce, C.M. 2003. Restoration of fragile histidine triad (FHIT) expression induces apoptosis and suppresses tumorigenicity in breast cancer cell lines. Cancer Res. 63: 1183-1187.

Shan, B. and Lee, W.H. 1994. Deregulated expression of E2F-1 induces S-phase entry and leads to apoptosis. Mol. Cell. Biol. 14: 8166-8173.

Shan, B., Farmer, A.A., and Lee, W.H. 1996. The molecular basis of E2F-1/DP-1-induced S-phase entry and apoptosis. Cell Growth Differ. 7: 689-697.

Sharma, S.V. and Settleman, J. 2006. Oncogenic shock: Turning an activated kinase against the tumor cell. Cell Cycle 5: 2878-2880.

Sharma, A., Trivedi, N.R., Zimmerman, M.A., Tuveson, D.A., Smith, C.D., and Robertson, G.P. 2005. Mutant V599EB-Raf regulates growth and vascular development of malignant melanoma tumors. Cancer Res. 65: 2412-2421.

Sharma, S.V., Fischbach, M.A., Haber, D.A., and Settleman, J. 2006a. 'Oncogenic shock': Explaining oncogene addiction through differential signal attenuation. Clin. Cancer Res. 12: 4392s-4395s

Sharma, S.V., Gajowniczek, P., Way, I.P., Lee, D.Y., Jiang, J., Yuza, Y., Classon, M., Haber, D.A., and Settleman, J. 2006b. A common signaling cascade may underlie 'addiction' to the Src, BCR-ABL, and EGF receptor oncogenes. Cancer Cell 10: 425-435.

Sharma, S.V., Bell, D.W., Settleman, J., and Haber, D.A. 2007. Epidermal growth factor receptor mutations in lung cancer. Nat. Rev. Cancer 7: 169-181.

Shawver, L.K., Schwartz, D.P., Mann, E., Chen, H., Tsai, J., Chu, L., Taylorson, L., Longhi, M., Meredith, S., Germain, L., et al. 1997. Inhibition of platelet-derived growth factor-mediated signal transduction and tumor growth by N-[4-(trifluoromethyl)-phenyl]5-methylisoxazole-4-carboxamide. Clin. Cancer Res. 3: 1167-1177.

Shchors, K. and Evan, G. 2007. Tumor angiogenesis: Cause or consequence of cancer? Cancer Res. 67: 7059-7061.

Shepard, H.M., Lewis, G.D., Sarup, J.C., Fendly, B.M., Maneval, D., Mordenti, J., Figari, I., Kotts, C.E., Palladino Jr., M.A., Ullrich, A., et al. 1991. Monoclonal antibody therapy of human cancer: Taking the HER 2 protooncogene to the clinic. $J$. Clin. Immunol. 11: 117-127.

Shi, Y., Glynn, J.M., Guilbert, L.J., Cotter, T.G., Bissonnette, R.P., and Green, D.R. 1992. Role for c-myc in activationinduced apoptotic cell death in T cell hybridomas. Science 257: 212-214.

Sikder, H.A., Devlin, M.K., Dunlap, S., Ryu, B., and Alani, R.M. 2003. Id proteins in cell growth and tumorigenesis. Cancer Cell 3: 525-530.

Sini, P., Wyder, L., Schnell, C., O'Reilly, T., Littlewood, A., Brandt, R., Hynes, N.E., and Wood, J. 2005. The antitumor and antiangiogenic activity of vascular endothelial growth factor receptor inhibition is potentiated by ErbB1 blockade. Clin. Cancer Res. 11: 4521-4532.

Skorski, T., Nieborowska-Skorska, M., Nicolaides, N.C., Szczylik, C., Iversen, P., Iozzo, R.V., Zon, G., and Calabretta, B. 1994. Suppression of Philadelphial leukemia cell growth in 
mice by BCR-ABL antisense oligodeoxynucleotide. Proc. Natl. Acad. Sci. 91: 4504-4508.

Smetsers, T.F., Skorski, T., van de Locht, L.T., Wessels, H.M., Pennings, A.H., de Witte, T., Calabretta, B., and Mensink, E.J. 1994. Antisense BCR-ABL oligonucleotides induce apoptosis in the Philadelphia chromosome-positive cell line BV173. Leukemia 8: 129-140.

Smeyne, R.J., Vendrell, M., Hayward, M., Baker, S.J., Miao, G.G., Schilling, K., Robertson, L.M., Curran, T., and Morgan, J.I. 1993. Continuous c-fos expression precedes programmed cell death in vivo. Nature 363: 166-169.

Smolen, G.A., Sordella, R., Muir, B., Mohapatra, G., Barmettler, A., Archibald, H., Kim, W.J., Okimoto, R.A., Bell, D.W., Sgroi, D.C., et al. 2006. Amplification of MET may identify a subset of cancers with extreme sensitivity to the selective tyrosine kinase inhibitor PHA-665752. Proc. Natl. Acad. Sci. 103: 2316-2321.

Soda, M., Choi, Y.L., Enomoto, M., Takada, S., Yamashita, Y., Ishikawa, S., Fujiwara, S., Watanabe, H., Kurashina, K., Hatanaka, H., et al. 2007. Identification of the transforming EML4-ALK fusion gene in non-small-cell lung cancer. $\mathrm{Na}$ ture 448: 561-566.

Soengas, M.S., Capodieci, P., Polsky, D., Mora, J., Esteller, M., Opitz-Araya, X., McCombie, R., Herman, J.G., Gerald, W.L., Lazebnik, Y.A., et al. 2001. Inactivation of the apoptosis effector Apaf-1 in malignant melanoma. Nature 409: 207-211.

Sola, F., Farao, M., Ciomei, M., Pastori, A., Mongelli, N., and Grandi, M. 1995. FCE 27266, a sulfonic distamycin derivative, inhibits experimental and spontaneous lung and liver metastasis. Invasion Metastasis 15: 222-231.

Solit, D.B., Garraway, L.A., Pratilas, C.A., Sawai, A., Getz, G., Basso, A., Ye, Q., Lobo, J.M., She, Y., Osman, I., et al. 2006. BRAF mutation predicts sensitivity to MEK inhibition. $\mathrm{Na}$ ture 439: 358-362.

Soncini, C., Carpinelli, P., Gianellini, L., Fancelli, D., Vianello, P., Rusconi, L., Storici, P., Zugnoni, P., Pesenti, E., Croci, V., et al. 2006. PHA-680632, a novel Aurora kinase inhibitor with potent antitumoral activity. Clin. Cancer Res. 12: 4080-4089.

Sordella, R., Bell, D.W., Haber, D.A., and Settleman, J. 2004. Gefitinib-sensitizing EGFR mutations in lung cancer activate anti-apoptotic pathways. Science 305: 1163-1167.

Soussi, T. 2007. p53 alterations in human cancer: More questions than answers. Oncogene 26: 2145-2156.

Stabile, L.P., Lyker, J.S., Huang, L., and Siegfried, J.M. 2004. Inhibition of human non-small cell lung tumors by a c-Met antisense/U6 expression plasmid strategy. Gene Ther. 11: 325-335.

Sumimoto, H., Miyagishi, M., Miyoshi, H., Yamagata, S., Shimizu, A., Taira, K., and Kawakami, Y. 2004. Inhibition of growth and invasive ability of melanoma by inactivation of mutated BRAF with lentivirus-mediated RNA interference. Oncogene 23: 6031-6039.

Tian, X.X., Pang, J.C., To, S.S., and Ng, H.K. 1999. Restoration of wild-type PTEN expression leads to apoptosis, induces differentiation, and reduces telomerase activity in human glioma cells. J. Neuropathol. Exp. Neurol. 58: 472-479.

Tokuda, Y., Ohnishi, Y., Shimamura, K., Iwasawa, M., Yoshimura, M., Ueyama, Y., Tamaoki, N., Tajima, T., and Mitomi, T. 1996. In vitro and in vivo anti-tumour effects of a humanised monoclonal antibody against c-erbB-2 product. Br. J. Cancer 73: 1362-1365.

Tokunaga, T., Tsuchida, T., Kijima, H., Okamoto, K., Oshika, Y., Sawa, N., Ohnishi, Y., Yamazaki, H., Miura, S., Ueyama, Y., et al. 2000. Ribozyme-mediated inactivation of mutant $\mathrm{K}$-ras oncogene in a colon cancer cell line. Br. J. Cancer 83:
833-839.

Trudel, S., Ely, S., Farooqi, Y., Affer, M., Robbiani, D.F., Chesi, M., and Bergsagel, P.L. 2004. Inhibition of fibroblast growth factor receptor 3 induces differentiation and apoptosis in $\mathrm{t}(4 ; 14)$ myeloma. Blood 103: 3521-3528.

Trudel, S., Li, Z.H., Wei, E., Wiesmann, M., Chang, H., Chen, C., Reece, D., Heise, C., and Stewart, A.K. 2005. CHIR-258, a novel, multitargeted tyrosine kinase inhibitor for the potential treatment of $\mathrm{t}(4 ; 14)$ multiple myeloma. Blood 105: 2941-2948.

Trudel, S., Stewart, A.K., Rom, E., Wei, E., Li, Z.H., Kotzer, S., Chumakov, I., Singer, Y., Chang, H., Liang, S.B., et al. 2006. The inhibitory anti-FGFR3 antibody, PRO-001, is cytotoxic to $\mathrm{t}(4 ; 14)$ multiple myeloma cells. Blood 107: 4039-4046.

Tsai, K.Y., Hu, Y., Macleod, K.F., Crowley, D., Yamasaki, L., and Jacks, T. 1998. Mutation of E2f-1 suppresses apoptosis and inappropriate $\mathrm{S}$ phase entry and extends survival of $\mathrm{Rb}-$ deficient mouse embryos. Mol. Cell 2: 293-304.

Tuveson, D.A., Willis, N.A., Jacks, T., Griffin, J.D., Singer, S., Fletcher, C.D., Fletcher, J.A., and Demetri, G.D. 2001. STI571 inactivation of the gastrointestinal stromal tumor c-KIT oncoprotein: Biological and clinical implications. Oncogene 20: 5054-5058.

Van Belle, E., Witzenbichler, B., Chen, D., Silver, M., Chang, L., Schwall, R., and Isner, J.M. 1998. Potentiated angiogenic effect of scatter factor/hepatocyte growth factor via induction of vascular endothelial growth factor: The case for paracrine amplification of angiogenesis. Circulation 97: 381-390.

Vater, C.A., Bartle, L.M., Dionne, C.A., Littlewood, T.D., and Goldmacher, V.S. 1996. Induction of apoptosis by tamoxifen-activation of a p53-estrogen receptor fusion protein expressed in E1A and T24 H-ras transformed p53 ${ }^{-1-}$ mouse embryo fibroblasts. Oncogene 13: 739-748.

Ventura, A., Kirsch, D.G., McLaughlin, M.E., Tuveson, D.A., Grimm, J., Lintault, L., Newman, J., Reczek, E.E., Weissleder, R., and Jacks, T. 2007. Restoration of p53 function leads to tumour regression in vivo. Nature 445: 661-665.

Vita, M. and Henriksson, M. 2006. The Myc oncoprotein as a therapeutic target for human cancer. Semin. Cancer Biol. 16: 318-330.

Vousden, K.H. and Lane, D.P. 2007. p53 in health and disease. Nat. Rev. Mol. Cell Biol. 8: 275-283.

Wang, H.G., Millan, J.A., Cox, A.D., Der, C.J., Rapp, U.R., Beck, T., Zha, H., and Reed, J.C. 1995. R-Ras promotes apoptosis caused by growth factor deprivation via a Bcl-2 suppressible mechanism. J. Cell Biol. 129: 1103-1114.

Watson, G.A., Queiroz de Oliveira, P.E., Stang, M.T., Armstrong, M.J., Gooding, W.E., Kuan, S.F., Yim, J.H., and Hughes, S.J. 2006. Ad-IRF-1 induces apoptosis in esophageal adenocarcinoma. Neoplasia 8: 31-37.

Webb, B.L., Jimenez, E., and Martin, G.S. 2000. v-Src generates a p53-independent apoptotic signal. Mol. Cell. Biol. 20: 9271-9280.

Weinstein, I.B. 2000. Disorders in cell circuitry during multistage carcinogenesis: The role of homeostasis. Carcinogenesis 21: 857-864.

Weinstein, I.B. 2002. Cancer. Addiction to oncogenes-The Achilles' heal of cancer. Science 297: 63-64.

Weinstein, I.B. and Joe, A.K. 2006. Mechanisms of disease: Oncogene addiction-A rationale for molecular targeting in cancer therapy. Nat. Clin. Pract. Oncol. 3: 448-457.

White, E. and Stillman, B. 1987. Expression of adenovirus E1B mutant phenotypes is dependent on the host cell and on synthesis of E1A proteins. J. Virol. 61: 426-435.

Wilkinson, R.W., Odedra, R., Heaton, S.P., Wedge, S.R., Keen, N.J., Crafter, C., Foster, J.R., Brady, M.C., Bigley, A., Brown, 
E., et al. 2007. AZD1152, a selective inhibitor of Aurora B kinase, inhibits human tumor xenograft growth by inducing apoptosis. Clin. Cancer Res. 13: 3682-3688.

Williams, R.T., Roussel, M.F., and Sherr, C.J. 2006. Arf gene loss enhances oncogenicity and limits imatinib response in mouse models of Bcr-Abl-induced acute lymphoblastic leukemia. Proc. Natl. Acad. Sci. 103: 6688-6693.

Williams, R.T., den Besten, W., and Sherr, C.J. 2007. Cytokinedependent imatinib resistance in mouse BCR-ABL ${ }^{+}$, Arf-null lymphoblastic leukemia. Genes \& Dev. 21: 2283-2287.

Wong, A.J., Bigner, S.H., Bigner, D.D., Kinzler, K.W., Hamilton, S.R., and Vogelstein, B. 1987. Increased expression of the epidermal growth factor receptor gene in malignant gliomas is invariably associated with gene amplification. Proc. Natl. Acad. Sci. 84: 6899-6903.

Wong, T.W., Lee, F.Y., Yu, C., Luo, F.R., Oppenheimer, S., Zhang, H., Smykla, R.A., Mastalerz, H., Fink, B.E., Hunt, J.T., et al. 2006. Preclinical antitumor activity of BMS-599626, a pan-HER kinase inhibitor that inhibits HER1/HER2 homodimer and heterodimer signaling. Clin. Cancer Res. 12: 6186-6193.

Woods, D., Parry, D., Cherwinski, H., Bosch, E., Lees, E., and McMahon, M. 1997. Raf-induced proliferation or cell cycle arrest is determined by the level of Raf activity with arrest mediated by p21Cip1. Mol. Cell. Biol. 17: 5598-5611.

Wu, X. and Levine, A.J. 1994. p53 and E2F-1 cooperate to mediate apoptosis. Proc. Natl. Acad. Sci. 91: 3602-3606.

Wu, C.H., van Riggelen, J., Yetil, A., Fan, A.C., Bachireddy, P., and Felsher, D.W. 2007. Cellular senescence is an important mechanism of tumor regression upon c-Myc inactivation. Proc. Nat1. Acad. Sci. 104: 13028-13033.

Xia, Z., Dickens, M., Raingeaud, J., Davis, R.J., and Greenberg, M.E. 1995. Opposing effects of ERK and JNK-p38 MAP kinases on apoptosis. Science 270: 1326-1331.

Xia, W., Mullin, R.J., Keith, B.R., Liu, L.H., Ma, H., Rusnak, D.W., Owens, G., Alligood, K.J., and Spector, N.L. 2002. Anti-tumor activity of GW572016: A dual tyrosine kinase inhibitor blocks EGF activation of EGFR/erbB2 and downstream Erk1/2 and AKT pathways. Oncogene 21: 6255-6263.

Xue, W., Zender, L., Miething, C., Dickins, R.A., Hernando, E., Krizhanovsky, V., Cordon-Cardo, C., and Lowe, S.W. 2007. Senescence and tumour clearance is triggered by p53 restoration in murine liver carcinomas. Nature 445: 656-660.

Yamazaki, H., Ohba, Y., Tamaoki, N., and Shibuya, M. 1990. A deletion mutation within the ligand binding domain is responsible for activation of epidermal growth factor receptor gene in human brain tumors. Jpn. J. Cancer Res. 81: 773-779.

Yamazaki, H., Kijima, H., Ohnishi, Y., Abe, Y., Oshika, Y., Tsuchida, T., Tokunaga, T., Tsugu, A., Ueyama, Y., Tamaoki, N., et al. 1998. Inhibition of tumor growth by ribozymemediated suppression of aberrant epidermal growth factor receptor gene expression. J. Natl. Cancer Inst. 90: 581-587.

Yano, S., Nakataki, E., Ohtsuka, S., Inayama, M., Tomimoto, H., Edakuni, N., Kakiuchi, S., Nishikubo, N., Muguruma, H., and Sone, S. 2005. Retreatment of lung adenocarcinoma patients with gefitinib who had experienced favorable results from their initial treatment with this selective epidermal growth factor receptor inhibitor: A report of three cases. Oncol. Res. 15: 107-111.

Yokouchi, H., Yamazaki, K., Kinoshita, I., Konishi, J., Asahina, H., Sukoh, N., Harada, M., Akie, K., Ogura, S., Ishida, T., et al. 2007. Clinical benefit of readministration of gefitinib for initial gefitinib-responders with non-small cell lung cancer. BMC Cancer 7: 51. doi: 10.1186/1471-2407-7-51.

Yokoyama, K. and Imamoto, F. 1987. Transcriptional control of the endogenous MYC protooncogene by antisense RNA.
Proc. Nat1. Acad. Sci. 84: 7363-7367.

Yoshimoto, A., Inuzuka, K., Kita, T., Kawashima, A., and Kasahara, K. 2007. Remarkable effect of gefitinib retreatment in a patient with nonsmall cell lung cancer who had a complete response to initial gefitinib. Am. J. Med. Sci. 333: 221-225.

Younes, M.N., Park, Y.W., Yazici, Y.D., Gu, M., Santillan, A.A., Nong, X., Kim, S., Jasser, S.A., El-Naggar, A.K., and Myers, J.N. 2006. Concomitant inhibition of epidermal growth factor and vascular endothelial growth factor receptor tyrosine kinases reduces growth and metastasis of human salivary adenoid cystic carcinoma in an orthotopic nude mouse model. Mol. Cancer Ther. 5: 2696-2705.

Zhou, X., Thorgeirsson, S.S., and Popescu, N.C. 2004. Restoration of DLC-1 gene expression induces apoptosis and inhibits both cell growth and tumorigenicity in human hepatocellular carcinoma cells. Oncogene 23: 1308-1313.

Zhu, J., Woods, D., McMahon, M., and Bishop, J.M. 1998. Senescence of human fibroblasts induced by oncogenic Raf. Genes \& Dev. 12: 2997-3007.

Zou, H.Y., Li, Q., Lee, J.H., Arango, M.E., McDonnell, S.R., Yamazaki, S., Koudriakova, T.B., Alton, G., Cui, J.J., Kung, P.P., et al. 2007. An orally available small-molecule inhibitor of c-Met, PF-2341066, exhibits cytoreductive antitumor efficacy through antiproliferative and antiangiogenic mechanisms. Cancer Res. 67: 4408-4417. 


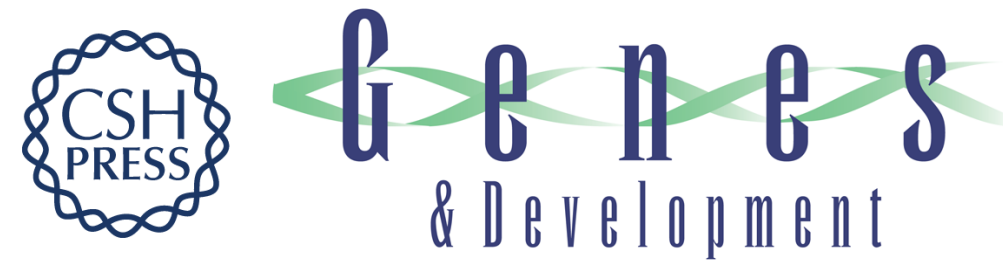

\section{Oncogene addiction: setting the stage for molecularly targeted cancer therapy}

Sreenath V. Sharma and Jeffrey Settleman

Genes Dev. 2007, 21:

Access the most recent version at doi:10.1101/gad.1609907

References This article cites 239 articles, 120 of which can be accessed free at: http://genesdev.cshlp.org/content/21/24/3214.full.html\#ref-list-1

License

Email Alerting Receive free email alerts when new articles cite this article - sign up in the box at the top Service right corner of the article or click here.

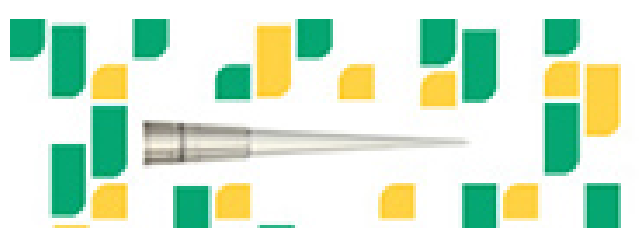

Focused on your science. 